\title{
Impact of industrial effluents on physico-chemical parameters of water and fatty acid profile of fish, Labeo rohita (Hamilton), collected from the Ramsar sites of Punjab, India
}

\author{
Navpreet $\operatorname{Kaur}^{1}$ (D) Onkar Singh Brraich ${ }^{1}$ \\ Received: 28 March 2020 / Accepted: 5 September 2021 / Published online: 18 September 2021 \\ (C) The Author(s), under exclusive licence to Springer-Verlag GmbH Germany, part of Springer Nature 2021
}

\begin{abstract}
In this contemporary era, wetlands and the entire aquatic diversity are suffering from major pollution problem. Not only the aggregation of higher population in metropolitan causes the production of plenty of solid, liquid and gaseous wastes, but also the high-technological industries contribute to a mammoth of wastes in the ecosystem. During the process of industrial effluent discharge into the water bodies, the toxic substances available in these wastes can affect the aquatic flora and fauna, resultantly disturbing the entire system and constituting human health hazards indirectly or directly. The objective of this study was to estimate the nutritional value of the liver and intestine of fish which is being discarded as waste during fish processing and pollution status by calculated water quality index (WQI) and comparison of both wetlands during diverse seasons. WQI of Harike Wetland was observed to be 56.68 which indicates that water quality in this wetland is "poor", while at Nangal Wetland WQI was calculated to be 39.54 and comes under "good" water quality and safe for the entire ecosystem. HPI (heavy metal pollution index) for Harike Wetland was observed 144.9 and for Nangal Wetland was 3.12, indicating heavy load of heavy metal pollution at test sample site. MI (metal index) value was also detected higher at test sample site (4.76) as compared to that at control site $(0.22)$. The mean total n-3 and n-6 polyunsaturated fatty acids (PUFAs) declined in the liver of test fish samples (Harike Wetland) as compared to control fish (Nangal Wetland) samples except in winter season. Similarly, mean total saturated fatty acids (SFAs) were also found to decline significantly $(p<0.05)$ in the liver of test fish sample as compared to control fish sample during autumn and winter seasons. Significant $(p<0.05)$ decline of mean total $n-3$ PUFAs (except winter) and total $n-6$ PUFAs (except rainy) in the intestine of test fish sample was observed during all the seasons when compared to control fish samples. However, total SFAs were found to increase in the intestine of test fish samples as compared to control fish samples during all the studied seasons. In the present investigation, fluctuations recorded in the water quality parameters and major groups of FAs in the tissues were due to the geographical location and pollution load in the fish samples taken from Harike Wetland.
\end{abstract}

Keywords Wetland pollution $\cdot$ Labeo rohita $\cdot$ WQI $\cdot$ Fish processing waste $\cdot$ Fatty acids $\cdot$ Liver $\cdot$ Intestine $\cdot$ Polyunsaturated fatty acids $\cdot$ Monounsaturated fatty acids $\cdot$ Seasonal variation $\cdot$ Nutritional value

\section{Introduction}

Pollution is a major problem of wetlands and constitutes a potential threat to the health and well-being of its entire

Responsible Editor: Philippe Garrigues

Navpreet Kaur

Navpreet22kaur@gmail.com

1 Department of Zoology and Environmental Sciences, Punjabi University, Patiala, Punjab 147002, India populations. The congregation of big communities in cities leads to the generation of large quantities of liquid, gaseous and solid wastes. Industries also contribute to colossal quantities of wastes of different nature. Wherever the intensification of industries, the process of treatment of industrial discharges has lagged far behind the industrial growth. The toxic substances present in these wastes can affect the aquatic life, thus disrupting the whole systems, and pose a threat to human health directly or indirectly (Pappa et al. 2016). The industrial wastes generally contains high quantities of dissolved and suspended solids, heavy metals, organic and inorganic chemicals, high BOD and COD, oils and grease, besides toxic 
metals which cause deleterious effects on the fish when discharged in to water bodies. In India, 50\% of human waste is discharged into water bodies, and majority of wetlands have been exploited for their natural cleansing capacity for assimilating various pollutants including heavy metals and pesticides (Joyce 2012; Anawar and Chowdhury 2020). Wetland plants and sediments accumulate various contaminants that enter the water through natural and anthropogenic activities which accumulated in fish tissues via the food chain; therefore, water, aquatic plants and fishes have been frequently used to assess wetland pollution all over the world and have been well grounded to be the biomarker of pollution load in water bodies (Kamal et al. 2004; Li et al. 2006; Adekola and Eletta 2007; Lu et al. 2011; Souza et al. 2013).

Nangal Wetland is located in the north-eastern part of Punjab and is surrounded by the Shivalik Hills. This wetland is a balancing reservoir situated over the Sutlej River (district, Ropar). The reservoirs are mainly used for storing extra water of the Sutlej River so that additional water of Bhakra Dam is discharged into the lake. During the time of draught circumstances, it provides water to tackle the draught conditions (Brraich and Jangu 2015a). The present study was carried out on Harike Wetland, and it was compared with Nangal Wetland. Harike Wetland is having significant role in various aspects particularly in economic, scientific, ecological, sociocultural as well as recreational purposes and also supports various threatened categories of plants and fishes and other faunal species (Kanaujja and Kumar 2014). Ludhiana City of Punjab is situated on the ridge of Buddha Nullah. With the increase in population, pressure and rapid growth of industrialization have brought various problems in the environment and also in Buddha Nullah. Ludhiana drains its polluted water into the Sutlej River after passing Buddha Nullah (Jaidka 2014). Nearby this river, more than 1100 different industries are present which discharge their effluent-rich water into Harike Wetland. Harike Wetland also receives polluted water from Kala Sanghian drain from Jalandhar district which is also enriched in industrial effluents. Due to discharge of polluted water in Harike Wetland, it became highly polluted, and various efforts have been chalked out to protect the wetlands from this undesirable pollution. Industrialization has put a high stress on fresh water resources which led to pollution problems in the water bodies of Punjab (Thakur et al. 2014).

Keeping in view the degrading conditions of Harike Wetland, the present study was aimed to estimate different metal contents along with other physico-chemical parameters of water and its impact on nutritional quality especially fatty acids of fish species in comparison with Nangal Wetland. In terms of nutritional quality, lipids, proteins and fatty acid compounds particularly PUFAs are available in fish which play an important role in protecting from various ailments, such as thrombosis, osteoporosis, macular degeneration, dementia, coronary heart disease, diabetes, some types of cancer, asthma and allergy (Oliver et al. 2020). Studies have also revealed the significance of eicosapentaenoic acid (EPA) and docosahexaenoic acid (DHA) extracted from fish and fish tissues that play a crucial role from the prevention of infection, lymphopenia, cytokine storm, leukopenia, excessive coagulation, hypoxemia and oxidative stress which have also been recorded in critically sick SARS-CoV-2 (severe acute respiratory syndrome coronavirus 2) patients in addition to the onset symptoms. There is still no approved vaccines. Dietary supplements could possibly improve the patient's recovery. EPA and DHA replace arachidonic acid in the phospholipid membranes. When oxidized by enzymes, DHA and EPA fatty acids contribute to the production of less inflammatory eicosanoids and specialized pro-resolving lipid mediators (SPMs), such as maresins, resolvins and protectins. This reduces inflammation (Rogero et al. 2020). These major PUFAs' incorporation in human diet is essential, because they are not produced in the human body (Jabeen and Chaudhry 2011). Alpha-linolenic acid, EPA, DHA, linoleic acid (Len) and arachidonic acid (AA) are the major PUFAs which have a significant role in human health maintenance (Abedi and Sahari 2014). Fish is a rich source of nutrition, and pollution will certainly affect its nutritional quality.

Not even physico-chemical but these pollutants available in water bodies and fish are very harmful and disturb the community-level structure, by ruining the very important food web which ultimately affects the human health (Verma and Saksena 2010; Khan and Hazarika 2012; Brraich and Jangu 2015a; Bashir et al. 2020). It has been reported that both natural and anthropogenic factors have led changes in the Harike Wetland area which besides disturbing the quality of water, also degrade the protein, lipids and fatty acid source in the form of fish food and limit their use (Baki et al. 2011; Javed et al. 2012).

The aim of this study was to investigate the seasonal variation and impact of industrial effluents on fatty acid profile of the liver and intestine of fish, Labeo rohita, collected live specimens from the Ramsar sites (Harike and Nangal) of Punjab, India, due to lack of information available on this topic. Moreover, this fish species is one of the most important commercial in northern and central India, Pakistan, Bangladesh and Myanmar among the three Indian major carps used in polyculture system. In India, it has been transplanted into almost all riverine systems. The species has also been introduced in many other countries, including Sri Lanka, Japan, Malaysia, the former USSR, China, the Philippines, some countries of Africa and Nepal.

\section{Materials and methods}

\section{Study area}

Nangal Wetland (Fig. 1) is placed over the Sutlej River at latitude $31^{\circ} 24^{\prime} 13.52^{\prime \prime} \mathrm{N}$ and longitude $76^{\circ} 22^{\prime} 03.05^{\prime \prime} \mathrm{E}$ with 


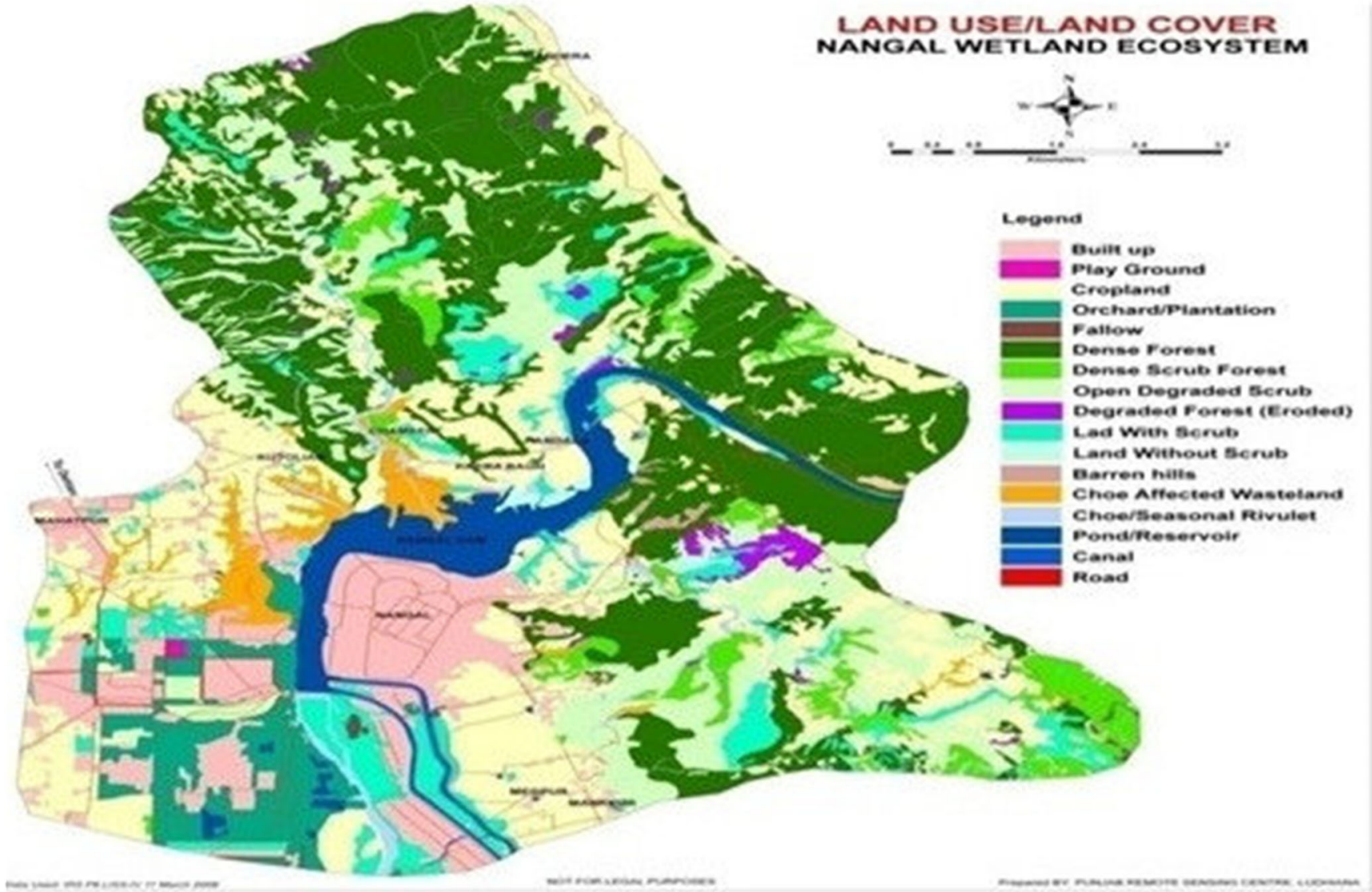

Fig. 1 View of Nangal Wetland (control site). (Source: https://www.researchgate.net/publication/318281037_ASSESSMENT_OF PHYSICOCHEMICAL_PARAMETERS_AND_WATER_QUALITY_INDEX_OF_NANGAL_WETLAND_PUNJAB_INDIA)

1172-ft elevation, situated in Ropar District. This region is enriched with diverse flora, fauna and hydrology covering land area of 700 acres; besides serving as an important refuelling base for migratory avifauna, this lake supports diversity of species of local birds, reptiles, fishes, some important plants and mammals. Due to the distinctive ecology of Nangal wetland, the Ministry of Environment and Forests of the Govt. of India in January 2008 has declared this wetland as National Wetland and included it under the National Lake Conservation Program. On August 10, 2009, it is also announced as a wildlife sanctuary (Brraich and Kaur 2015).

Harike Wetland spreads over 4100-ha area (Figure 2). In 1990, the studied wetland was included into the list of Ramsar sites. Harike Wetland is situated at latitude of $31.17^{\circ} \mathrm{N}$ and longitude of $75.20^{\circ} \mathrm{E}$. This wetland is also significant because it is situated on the confluence of two rivers of the Indus River system, i.e. Sutlej and Beas. This is a riverine wetland, but due to large area it supports diverse type of habitats like lacustrine, palustrine and swamps. It supports immense variety of valuable fauna and flora. Unluckily over the years, this important aquatic ecosystem receives huge quantity of untreated industrial effluents from nearby cities through the inflow rivers which are posing a severe hazard to its existence. A fastspreading weed, water hyacinth, Eichhornia crassipes
(Mart.) Solms, growth has been enhanced by raw sewage and industrial waste disposal from the upstream towns and villages along the rivers covering a great area in the Harike Wetland which has reduced its size. The turbidity of the water in both rivers is also variable, with Beas carrying most of the sediments into the wetland, while the water of Sutlej River is almost black due to the discharge of industrial waste and sewage water upstream in the industrialized city of Ludhiana, Punjab. The impact of the polluted water has viciously spread to other areas of southern Punjab and to Rajasthan, through the Harike waterworks (Brraich and Jangu 2015b).

\section{Analysis of WQI, HPI and MI}

Water samples were collected in 1-1 reagent bottle during morning hours during different seasons, i.e. rainy (July to September), autumn (September to November) and winter (December to February) of the year from July 2018 to February 2019 from Harike and Nangal wetlands in triplicates from each site, and their mean and standard deviation calculated. Physico-chemical parameters such as water temperature, DO, total dissolved solids (TDS) and $\mathrm{pH}$ were analysed on the spot with the help of water analysis kit. Total alkalinity 


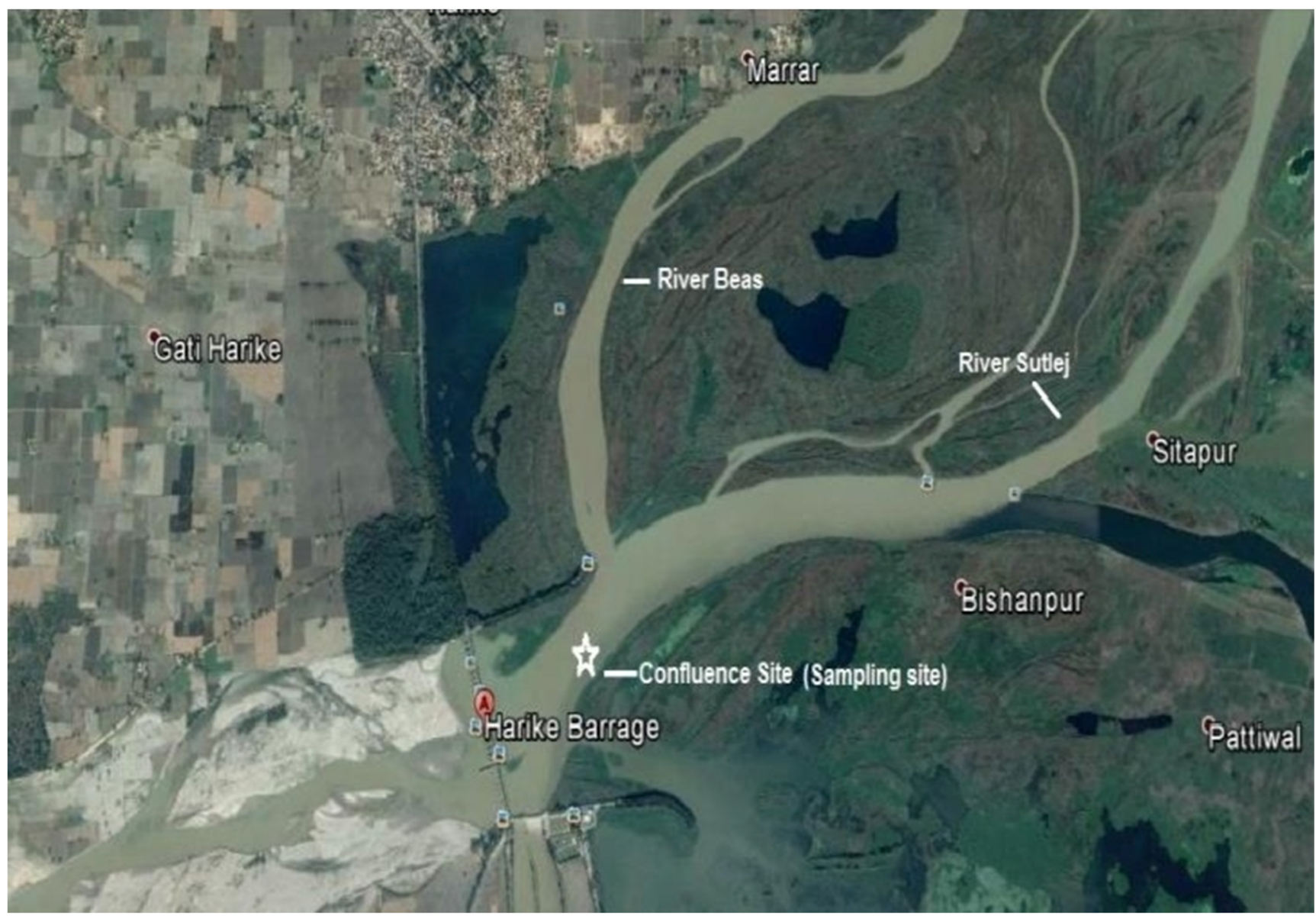

Fig. 2 View of Harike Wetland (polluted site). (Source: http://www.ijsrp.org/research-paper-0215.php?rp=P383729)

and salinity and heavy metals were analysed in the laboratory by standard methods (Trivedi and Goel 1984; APHA 2012).

\section{Water quality index (WQI) computation}

Alkalinity, TDS, $\mathrm{pH}$ and DO parameters were detected on seasonal basis in triplicates at each wetland during individual season to calculate WQI.

Weighted arithmetic WQI method classified the water quality according to the degree of purity by using the most commonly measured water quality variables. The method has been widely used by various scientists, and the calculation of WQI was made by using the following equation (Brown et al. 1972):

$\mathrm{WQI}=\Sigma \mathrm{Q}_{\mathrm{i}} \mathrm{W}_{\mathrm{i}} / \Sigma \mathrm{W}_{\mathrm{i}}$

The quality rating scale $(Q i)$ for each parameter is calculated by using this expression

$\mathrm{Q}_{\mathrm{i}}=100\left[\left(\mathrm{~V}_{\mathrm{i}}-\mathrm{V}_{\mathrm{o}} / \mathrm{S}_{\mathrm{i}}-\mathrm{V}_{\mathrm{o}}\right)\right]$

where $V i$ is the estimated concentration of ith parameter in the analysed water, $V o$ is the ideal value of this parameter in pure water $V o=0($ except $\mathrm{pH}=7.0$ and $\mathrm{DO}=14.6 \mathrm{mg} / \mathrm{l})$ and $S i$ is the recommended standard value of ith parameter. The unit weight $(W i)$ for each water quality parameter is calculated by using the following formula:

$\mathrm{W}_{\mathrm{i}}=\mathrm{K} / \mathrm{S}_{\mathrm{i}}$

where $K$ is the proportionality constant and can also be calculated by using the following equation:

$\mathrm{K}=1 / \sum\left(1 / \mathrm{S}_{\mathrm{i}}\right)$

Heavy metal pollution index (HPI) computation Heavy metal pollution index (HPI) is a method developed by assigning a rating or weightage (Wi) for each parameter that shows the composite influence of individual heavy metal on the overall quality of water. The rating is a value between 0 and 1 , and it reflects the importance of individual quality considerations. Wi is inversely proportional to the permissible limit value given in the standard (Mohan et al. 1996)

$\mathrm{W}_{\mathrm{i}}=\mathrm{k} / \mathrm{S}_{i}$ 
where $W i$ is the unit weightage, $S i$ is the permissible value given in the standard for each parameter and $k$ is the constant of proportionality.

$$
\begin{aligned}
& \frac{\mathrm{n}\left\{\underline{\mathrm{M}(}\left(-\mathrm{l}_{1}\right)\right\}}{\mathrm{Q}_{\mathrm{i}}=\sum \mathrm{S}_{1}-\mathrm{l}_{1} \quad i=1}
\end{aligned}
$$

where $Q i$ is the sub-index of ith parameter, $M i$ is the analysed result of the ith parameter in $\mu \mathrm{g} / \mathrm{l}, \mathrm{Si}$ is the permissible limit value given in the standard for the ith parameter and $I i$ the ideal value of the ith parameter. The sign (-) means that algebraic sign will be ignored and only the numerical difference of the two values will be used in the calculation.

$\mathrm{HPI}=\sum \mathrm{Q}_{\mathrm{i}} \mathrm{W}_{\mathrm{i}} / \sum \mathrm{W}_{\mathrm{i}}$

where $Q i$ is the sub-index of ith parameter, $W i$ is the unit weightage for each parameter and $n$ is the number of parameters. MI was calculated according to Caerio et al. (2005).

A total of 30 live fish specimens of Labeo rohita (Hamilton) more than 500g (mature specimens ready for harvesting) were collected from the Nangal and Harike wetlands during different seasons. At collection sites, the biometric data (Table 1) was taken on the spot, and each fish was individually wrapped in labelled clean airtight ziplock polythene bags and embedded in abundant crushed ice in an ice box and transported into the laboratory. In the fisheries laboratory, the fish samples were washed with tap water and thawed to remove the ice from fish. The liver and intestine (fish waste) after dissection were removed from the fish, and their weights were recorded. During every season, composite samples of the liver and intestine were prepared by separately pooling together of each organ to form composite sample and stored $-20^{\circ} \mathrm{C}$ in the freezer until analysed for TLC and FA composition (Kaur et al. 2018). The stored/frozen composite samples (3 from each organ of each season) were thawed for 3-4 h at and were soaked on filter paper before weighing. A total of $10 \mathrm{~g}$ of each composite sample was put in a filter paper thimble prepared by folding $22 \times 25$-cm sheet of filter paper rolled and tied with a thread to fit into the extraction tube of Soxhlet apparatus with cotton at lower closed end of the thimble. The washed sample was made to sit on the top of the cotton. TLC were extracted with $125-\mathrm{ml}$ petroleum ether in $250-\mathrm{ml}$ flask of Soxhlet apparatus for $8 \mathrm{~h}$ at $60-80^{\circ} \mathrm{C}$. The contents of the $125-$ $\mathrm{ml}$ flask were transferred in a previously weighed crucible. The excess ether was evaporated at $80^{\circ} \mathrm{C}$ in a hot air oven. The crucible was cooled and weighed. The process of heating and weighing after cooling was repeated until constant weight of crucible was obtained and then stored in airtight glass vials for fatty acid estimation. Soxhlet lipid extraction/solvent extraction method (A.A.C.C. 1976) was used for the TLC (\%) estimation of each organ in triplicates in every season.
Gas liquid chromatography (A.O.A.C. 2000) was used for the qualitative and quantitative analysis of FA composition (\%) and also, determined triplicate analysis of each organ in individual season. For FA analysis, methyl esters of extracted fish liver and intestine lipids were prepared using $8 \%$ sodium chloride (Nacl) and sodium ethylate $\left(\mathrm{CH}_{3} \mathrm{CH}_{2} \mathrm{ONa}\right)(0.02 \mathrm{M})$ (Applequist et al. 1968). Two microlitre of sample was injected by using a microsyringe (Hamilton). In the oven of M/s Nucon Engineers AIMIL Gas Chromatograph (solid state) model, Nucon series 5700/5765 is equipped with flame ionization detector fitted with SS column $1 / 8$ " outer diameter $\times 2 \mathrm{M}$ length, packed with $15 \%$ DEGS on CHROMOSORB WHP, 80-100 mesh size. The conditions for the separation were oven temperature $200^{\circ} \mathrm{C}$, injector temperature $230^{\circ} \mathrm{C}$, detector temperature $240^{\circ} \mathrm{C}$, hydrogen flow $30 \mathrm{ml} / \mathrm{min}$, air flow $300 \mathrm{ml} / \mathrm{min}$ and nitrogen flow $40 \mathrm{ml} / \mathrm{min}$. Identification of peaks was done by comparison of their retention time with those of standard fatty acyl esters (MP Biomedicals Inc., USA). Relative concentration of FAs was calculated by use of an automatic integrator Windows-based AIMIL Ltd., DASTA 710 Gas Chromatograph Data station software, version WinAcds 7.1.

\section{Results}

\section{Analysis of physico-chemical parameters}

The study on Nangal and Harike wetlands was carried out from June 2018 to February 2019 to investigate quality of water at three representative sites of each wetland and calculated their mean and standard deviation during individual season which is depicted in Table 2. Nangal Wetland: water temperature $\left({ }^{\circ} \mathrm{C}\right)$ ranged between 18.6 and $26.0(22.5 \pm 2.83)$ and recorded maximum (24.5) in rainy and minimum (19.5) in winter season. $\mathrm{pH}$ varied 7.0-8.8 (7.8 \pm 0.61$)$ observed highest (8.5) in rainy and lowest (7.2) in autumn. Alkalinity (mg/l) ranged between 42.4 and $64(53.0 \pm 6.96)$ recorded maximum (60.0) also in rainy and minimum (45.0) in winter. DO ranged between 7.8 and $9.0(8.2 \pm 0.33)$ recorded maximum (8.5) in rainy and minimum (8.0) in winter. TDS ranged between 114 and $124(117.6 \pm 3.16)$ recorded maximum (120) in rainy and minimum value (115) observed in winter. Harike wetland: The value of temperature $\left({ }^{\circ} \mathrm{C}\right)$ ranged between 22.0 and 27.0 (24.1 \pm 1.88$)$. The maximum value (26.5) of water temperature $\left({ }^{\circ} \mathrm{C}\right)$ recorded in rainy and minimum (22.2) in winter season. The value of hydrogen ion $(\mathrm{pH})$ ranged between 7.2 and 9.0 $(8.0 \pm 0.63)$. The maximum $\mathrm{pH}$ value (8.7) was recorded in rainy and minimum (7.3) in autumn. Alkalinity $(\mathrm{mg} / \mathrm{l})$ ranged between 56 and $62(60 \pm 1.92)$ recorded maximum (61.3) in winter and minimum (58.0) in autumn. DO ranged between 7.8 and $8.2(7.9 \pm 0.13)$ recorded maximum (8.0) in winter and minimum (7.9) in autumn. TDS ranged between 216 and 227 
Table 1 Mean biometric data ( $\mathrm{cm}$ and g) of Labeo rohita collected from Nangal Wetland (control site) and Harike Wetland (Polluted site) during different seasons

\begin{tabular}{|c|c|c|c|c|c|c|c|c|c|c|}
\hline \multirow{2}{*}{$\begin{array}{l}\text { Sites } \\
\text { Seasons }\end{array}$} & \multirow[b]{2}{*}{ Fish. no. } & \multirow[b]{2}{*}{$\begin{array}{l}\text { Total } \\
\text { length }(\mathrm{cm})\end{array}$} & \multicolumn{3}{|c|}{ Nangal Wetland (control site) } & \multirow[t]{2}{*}{ Seasons } & \multicolumn{4}{|c|}{ Harike Wetland (polluted site) } \\
\hline & & & $\begin{array}{l}\text { Standard } \\
\text { length }(\mathrm{cm})\end{array}$ & $\begin{array}{l}\text { Body } \\
\text { width }(\mathrm{cm})\end{array}$ & $\begin{array}{l}\text { Body } \\
\text { weight }(g)\end{array}$ & & $\begin{array}{l}\text { Total } \\
\text { length }(\mathrm{cm})\end{array}$ & $\begin{array}{l}\text { Standard } \\
\text { length }(\mathrm{cm})\end{array}$ & $\begin{array}{l}\text { Body } \\
\text { width }(\mathrm{cm})\end{array}$ & $\begin{array}{l}\text { Body } \\
\text { weight (g) }\end{array}$ \\
\hline \multirow[t]{7}{*}{ Rainy } & 1. & 43.5 & 36.1 & 9.1 & 902 & \multirow[t]{7}{*}{ Rainy } & 48.2 & 40.2 & 11.9 & 1590 \\
\hline & 2. & 51.5 & 44.2 & 15.4 & 2294 & & 45.5 & 41.2 & 11.4 & 1440 \\
\hline & 3. & 33.1 & 27.1 & 8.2 & 528 & & 57.7 & 47.7 & 17.9 & 2801 \\
\hline & 4. & 33.3 & 26.5 & 8.8 & 598 & & 47.0 & 39.0 & 11.7 & 1482 \\
\hline & 5. & 35.1 & 27.4 & 9.2 & 608 & & 50.3 & 41.6 & 12.2 & 1834 \\
\hline & 6. & 33.5 & 28.5 & 9 & 603 & & 57.6 & 47.7 & 17.9 & 2800 \\
\hline & 7. & 32.2 & 26.9 & 7.9 & 572 & & 49.5 & 42.5 & 12.2 & 1596 \\
\hline \multirow[t]{13}{*}{ Autumn } & 8. & 51.5 & 43.6 & 12.2 & 1741 & \multirow[t]{8}{*}{ Autumn } & 51.2 & 42.7 & 12.5 & 1941 \\
\hline & 9. & 38.9 & 31.2 & 8.5 & 849 & & 50.5 & 41.8 & 12.3 & 1837 \\
\hline & 10. & 39.1 & 30.5 & 8.6 & 848 & & 46.9 & 38.6 & 11.7 & 1480 \\
\hline & 11. & 38.8 & 31 & 8.5 & 842 & & 42.3 & 36.2 & 10.3 & 1331 \\
\hline & 12. & 39.3 & 31 & 8.9 & 854 & & 51.2 & 42.7 & 12.5 & 1941 \\
\hline & 13. & 40.1 & 36.8 & 9 & 740 & & 55.9 & 46.2 & 14.2 & 3488 \\
\hline & 14. & 39.8 & 32.2 & 8.9 & 729 & & 57.2 & 47.3 & 17.7 & 2793 \\
\hline & 15. & 36 & 29.8 & 8.1 & 838 & & 58.5 & 49.8 & 18 & 2801 \\
\hline & 16. & 36.7 & 30.1 & 8.3 & 840 & \multirow[t]{5}{*}{ Winter } & 39.2 & 32.8 & 7.9 & 849 \\
\hline & 17. & 35.7 & 28.8 & 8 & 839 & & 38.2 & 31.3 & 7.7 & 843 \\
\hline & 18. & 34.9 & 28.8 & 7.8 & 790 & & 36.2 & 30.7 & 7.5 & 838 \\
\hline & 19. & 37.3 & 30.3 & 8.5 & 848 & & 32.5 & 26.5 & 6.3 & 820 \\
\hline & 20. & 36.9 & 29.1 & 8.2 & 850 & & 34.8 & 27.7 & 6.5 & 830 \\
\hline \multirow[t]{10}{*}{ Winter } & 21. & 43.5 & 35.5 & 10.2 & 1461 & & 45.5 & 41.3 & 11.4 & 1440 \\
\hline & 22. & 42.5 & 35 & 10.1 & 1338 & & 47.8 & 42.2 & 11.7 & 1582 \\
\hline & 23. & 40.2 & 33.2 & 9.5 & 1282 & & 40.4 & 34.3 & 9.9 & 1292 \\
\hline & 24. & 43.2 & 33.5 & 9.8 & 1457 & & 40.9 & 34.8 & 10.1 & 1297 \\
\hline & 25. & 43.5 & 35.5 & 9.9 & 1461 & & 37.1 & 32.1 & 7.6 & 842 \\
\hline & 26. & 41.5 & 35.8 & 7.8 & 1323 & & 46.3 & 42.2 & 11.6 & 1452 \\
\hline & 27. & 40.0 & 33.0 & 9.5 & 1281 & & 40.8 & 34.6 & 10.1 & 1298 \\
\hline & 28. & 39.9 & 32.9 & 9.4 & 1280 & & 40.4 & 34.3 & 9.6 & 1292 \\
\hline & 29. & 40.1 & 33.1 & 9.4 & 1279 & & 46.8 & 42.5 & 11.8 & 1480 \\
\hline & 30. & 41.9 & 35.9 & 9.8 & 1340 & & 34.9 & 27.6 & 6.6 & 835 \\
\hline $\begin{array}{l}\text { Mean } \\
\quad \pm \text { S.E }\end{array}$ & & $39.4 \pm 0.8$ & $32.44 \pm 0.7$ & $9.2 \pm 0.2$ & $1040 \pm 73.8$ & & $45.7 \pm 1.3$ & $38.6 \pm 1.1$ & $11.3 \pm 0.6$ & $1604 \pm 128$ \\
\hline
\end{tabular}

$(220 \pm 4.55)$ detected maximum (224) in winter and minimum (218) in rainy (Table 3).

Evaluation of water quality on the basis of WQI WQI can be defined as the index which reflects the combinational effect of various water quality parameters and provides a single number which gives information about the overall water quality of studied water body (Akhter and Brraich 2020). To assess the water quality role in fish FAs, public usage and other purposes, we estimated WQI at three representative sites of

Table 2 Seasonal values of selected water quality parameters (Mean \pm S.D.) from Nangal and Harike wetlands during diverse seasons

\begin{tabular}{|c|c|c|c|c|c|c|c|c|c|c|c|c|}
\hline \multirow{3}{*}{ Parameters } & \multicolumn{6}{|c|}{ Nangal } & \multicolumn{6}{|c|}{ Harike } \\
\hline & \multicolumn{2}{|l|}{ Rainy } & \multicolumn{2}{|c|}{ Autumn } & \multicolumn{2}{|c|}{ Winter } & \multicolumn{2}{|l|}{ Rainy } & \multicolumn{2}{|c|}{ Autumn } & \multicolumn{2}{|l|}{ Winter } \\
\hline & Mean & S.D. & Mean & S.D. & Mean & S.D. & Mean & S.D. & Mean & S.D. & Mean & S.D. \\
\hline Water temperature $\left({ }^{\circ} \mathrm{C}\right)$ & 24.5 & 1.01 & 23.5 & 3.02 & 19.5 & 0.90 & 26.5 & 0.57 & 24.0 & 1.31 & 22.2 & 0.25 \\
\hline pH & 8.5 & 0.25 & 7.2 & 0.2 & 7.9 & 0.23 & 8.7 & 0.32 & 7.3 & 0.1 & 8.1 & 0.25 \\
\hline Alkalinity (mg/l) & 60.0 & 4.0 & 54.1 & 1.04 & 45.0 & 2.30 & 60 & 1.0 & 58 & 2.0 & 61.3 & 1.15 \\
\hline Dissolved oxygen (mg/l) & 8.5 & 0.40 & 8.26 & 0.20 & 8.0 & 0.2 & 7.8 & 0.05 & 7.9 & 0.1 & 8.0 & 0.11 \\
\hline Total dissolved solids (ppm) & 120 & 3.60 & 118 & 2.64 & 115 & 1.0 & 218 & 2.08 & 220 & 4.0 & 224 & 2.51 \\
\hline
\end{tabular}


Table 3 Values of selected different physico-chemical parameters of Nangal and Harike wetlands during June 2018 to February 2019 compared to other prescribed values

\begin{tabular}{|c|c|c|c|c|c|c|c|}
\hline \multirow[t]{2}{*}{ Parameters } & \multicolumn{2}{|l|}{ Nangal } & \multicolumn{2}{|l|}{ Harike } & \multirow[t]{2}{*}{ WHO (1992) } & \multirow[t]{2}{*}{ ISI (1973) } & \multirow[t]{2}{*}{ ICMR (1975) } \\
\hline & Mean \pm S.D. & Range & Mean \pm S.D. & Range & & & \\
\hline Water temperature $\left({ }^{\circ} \mathrm{C}\right)$ & $22.5 \pm 2.83$ & $18.6-26.0$ & $24.1 \pm 1.88$ & $22.0-27.0$ & - & - & - \\
\hline pH & $7.8 \pm 0.61$ & $7.0-8.8$ & $8.0 \pm 0.63$ & $7.2-9.0$ & $6.5-8.5$ & $6.5-8.5$ & 7.74 \\
\hline Alkalinity (mg/l) & $53.0 \pm 6.96$ & $42.4-64$ & $60 \pm 1.92$ & $56-62$ & 120 & 200 & 120 \\
\hline Dissolved oxygen (mg/l) & $8.2 \pm 0.33$ & $7.8-9.0$ & $7.9 \pm 0.13$ & $7.8-8.2$ & 5.0 & - & 5.0 \\
\hline Total dissolved solids (ppm) & $117.6 \pm 3.16$ & $114-124$ & $220 \pm 4.55$ & $216-227$ & 500 & 500 & 500 \\
\hline
\end{tabular}

Nangal and Harike wetlands on the basis of various physicochemical parameters, for instance, $\mathrm{DO}, \mathrm{pH}$, alkalinity and TDS. The average values of physico-chemical parameters were compared with the Indian Council of Medical Research (ICMR 1975); national and international standards for drinking water quality, viz. Indian Standard Institute (ISI 1973); and World Health Organization (WHO 1992) depicted in Table 3. All studied parameters come under permissible limits of drinking water except $\mathrm{pH}$. Higher values of $\mathrm{pH}$, alkalinity and TDS were observed at Harike Wetland as compared to Nangal Wetland. Harike Wetland receives high concentration of pollutants, and industrial effluents reached via Buddha Nullah which carries industrial waste of almost 1060 industries of Ludhiana City. Hence, WQI of Harike Wetland was found to be 56.68 (Table 4); it could be concluded that water quality at this wetland is "poor" which can have toxic effect on ecosystem and is unfit for human usage according to the values given by Chatterji and Raziuddin (2002) presented in Table 5. However, WQI of Nangal Wetland was observed to be 39.54 and comes under "good" water quality and safe for the entire ecosystem (Chatterji and Raziuddin 2002) (Table 5).

\section{Heavy metal analysis in water samples}

Heavy metal pollution is a severe ecosystem problem in every nook and corner of the world due to persistent toxic, nonbiodegradable and bioaccumulating properties of these toxicants. The average values of heavy metals recorded in water from Nangal and Harike wetlands during diverse seasons is depicted in Table 6 . The majority of heavy metals detected in the water of Harike Wetland are above tolerable limits when compared with WHO standards; however, heavy metals observed in the water of Nangal Wetland were within permissible limits in the present course of the study.

The study on Nangal and Harike wetlands was carried out from June 2018 to February 2019 to investigate heavy metals in water samples at three representative sites of each wetland and calculated their mean and standard deviation during individual season which is depicted in Table 6. The average values of arsenic (As), boron $(\mathrm{B})$, cadmium $(\mathrm{Cd})$, cobalt $(\mathrm{Co})$, chromium $(\mathrm{Cr})$, copper $(\mathrm{Cu})$, iron $(\mathrm{Fe})$, manganese $(\mathrm{Mn})$, nickel $(\mathrm{Ni})$, lead $(\mathrm{Pb})$ and zinc $(\mathrm{Zn})$ are $0.0002(\mathrm{mg} / 1)$, 0.0387 (mg/l), 0.00018 (mg/l), 0.0076 (mg/l), 0.0041 $(\mathrm{mg} / \mathrm{l}), 0.0311(\mathrm{mg} / \mathrm{l}), 0.0075$ (mg/1), 0.0059 (mg/1), $0.00(\mathrm{mg} / \mathrm{l}), 0.00(\mathrm{mg} / \mathrm{l})$ and $0.0014(\mathrm{mg} / \mathrm{l})$, respectively, at Nangal Wetland, while $0.0122(\mathrm{mg} / \mathrm{l}), 0.076(\mathrm{mg} / \mathrm{l})$, $0.0104(\mathrm{mg} / \mathrm{l}), 0.0062(\mathrm{mg} / \mathrm{l}), 0.0175$ (mg/1), 0.0313 $(\mathrm{mg} / \mathrm{l}), 0.0152(\mathrm{mg} / \mathrm{l}), 0.0059(\mathrm{mg} / \mathrm{l}), 0.0158(\mathrm{mg} / \mathrm{l})$, $0.0108(\mathrm{mg} / \mathrm{l})$ and $0.0075(\mathrm{mg} / \mathrm{l})$, respectively, at Harike Wetland (Tables 7 and 8 ).

\section{Heavy metal pollution index (HPI) and metal index (MI)}

Effective tool to characterize the surface water pollution is referred to as heavy metal pollution index. It combines with various parameters to arrive at a particular value to estimate the level of pollution load in water bodies. Mean concentration of the eleven heavy metals was used to calculate HPI at both the sites. Overall HPI for Harike Wetland was found to be 144.98 and for Nangal Wetland was observed to be 3.1208 (Tables 7 and 8). HPI determined for Harike Wetland is above the critical value indicated that this wetland is critically contaminated with respect to heavy metals (Table 9). However, HPI calculated value represented at Nangal Wetland showed that this wetland is safe with respect to heavy metal pollution that is why we selected this as control site in the present study.

The metal pollution index of all the heavy metals had been calculated individually using the standards. At Harike Wetland including all the seasons, the metal index value of all the metals was found to be 4.76965 , while at Nangal Wetland was 0.2237 (Tables 10 and 11). The recorded results of indices showed that the MI for all the metals at Harike Wetland comes under strongly affected category of pollution proposed for drinking water (Table 12). 


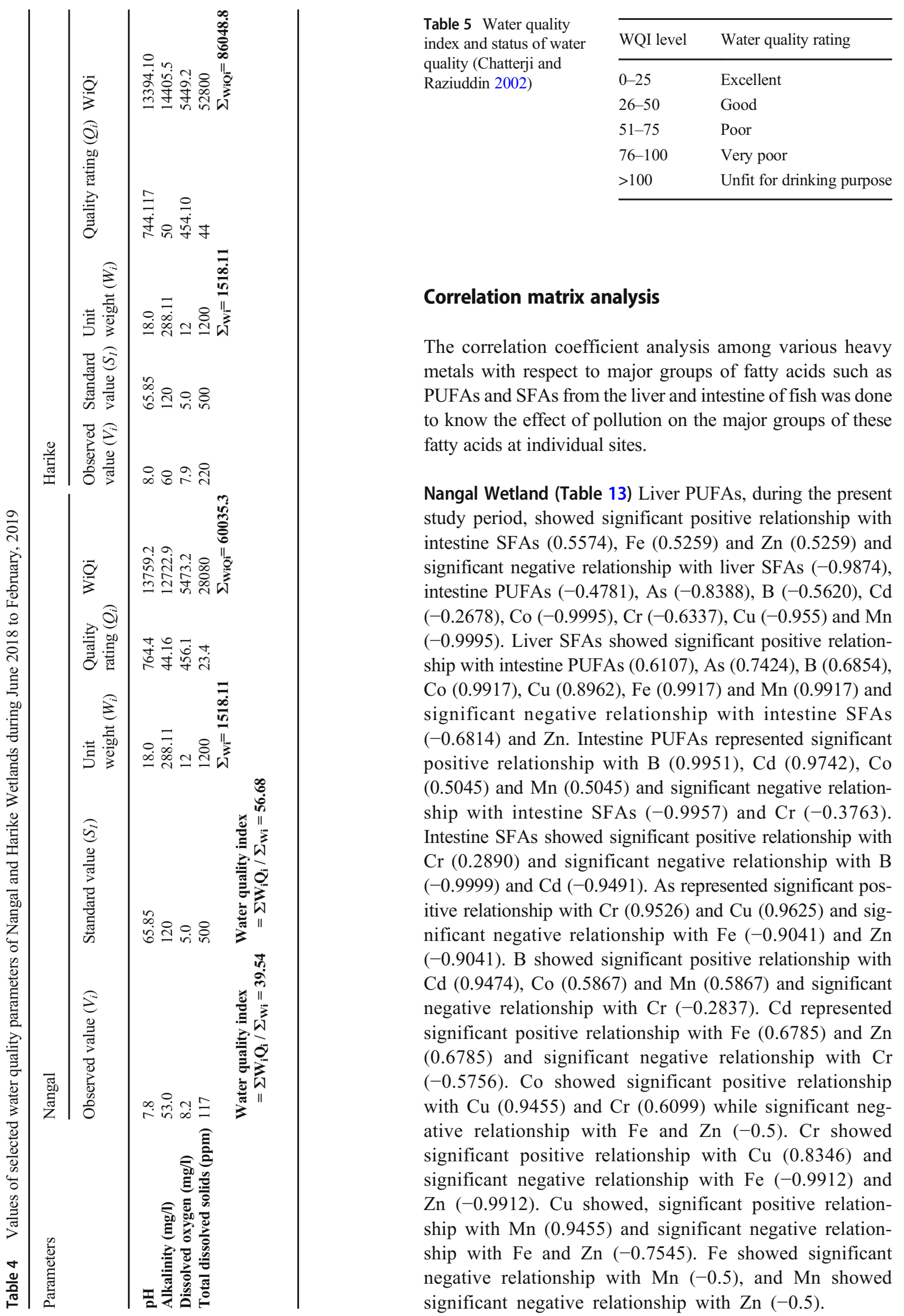


Table 6 Heavy metal analysis (mean and S.D.) of water samples (ppm) from Nangal and Harike wetlands during different seasons

\begin{tabular}{|c|c|c|c|c|c|c|c|c|c|c|c|c|}
\hline \multirow{3}{*}{ Parameters } & \multicolumn{6}{|l|}{ Nangal } & \multicolumn{6}{|l|}{ Harike } \\
\hline & \multicolumn{2}{|l|}{ Rainy } & \multicolumn{2}{|l|}{ Autumn } & \multicolumn{2}{|l|}{ Winter } & \multicolumn{2}{|l|}{ Rainy } & \multicolumn{2}{|c|}{ Autumn } & \multicolumn{2}{|l|}{ Winter } \\
\hline & Mean & S.D. & Mean & S.D. & Mean & S.D. & Mean & S.D. & Mean & S.D. & Mean & S.D. \\
\hline As & 0.00016 & 0.0001 & 0.00023 & 0.00015 & 0.0002 & 0.00 & 0.0133 & 0.005 & 0.0133 & 0.005 & 0.01 & 0.00 \\
\hline B & 0.0471 & 0.0008 & 0.0508 & 0.005 & 0.0181 & 0.0098 & 0.0162 & 0.009 & 0.1463 & 0.004 & 0.0675 & 0.0117 \\
\hline Cd & 0.00023 & 0.0001 & 0.0002 & 0.00 & 0.0106 & 0.001 & 0.0106 & 0.001 & 0.01 & 0.00 & 0.0106 & 0.0015 \\
\hline Co & 0.0052 & 0.0002 & 0.0124 & 0.005 & 0.0052 & 0.002 & 0.0068 & 0.0010 & 0.0075 & 0.001 & 0.0045 & 0.002 \\
\hline $\mathrm{Cr}$ & 0.0024 & 0.001 & 0.0052 & 0.002 & 0.0048 & 0.001 & 0.0152 & 0.0018 & 0.0180 & 0.009 & 0.0181 & 0.004 \\
\hline $\mathrm{Cu}$ & 0.007 & 0.001 & 0.0613 & 0.035 & 0.025 & 0.013 & 0.0070 & 0.00 & 0.0616 & 0.0347 & 0.0253 & 0.0134 \\
\hline $\mathrm{Fe}$ & 0.0123 & 0.005 & 0.0052 & 0.002 & 0.0052 & 0.002 & 0.0127 & 0.001 & 0.0207 & 0.0001 & 0.0156 & 0.008 \\
\hline Mn & 0.0052 & 0.0006 & 0.0074 & 0.001 & 0.0052 & 0.00 & 0.00518 & 0.001 & 0.0071 & 0.001 & 0.0054 & 0.001 \\
\hline $\mathbf{N i}$ & - & - & - & - & - & - & 0.0133 & 0.004 & 0.0193 & 0.0041 & 0.0150 & 0.005 \\
\hline $\mathbf{P b}$ & - & - & - & - & - & - & 0.0108 & 0.0016 & 0.0108 & 0.0016 & 0.0108 & 0.0015 \\
\hline Zn & 0.0024 & 0.0007 & 0.001 & 0.00 & 0.001 & 0.00 & 0.0052 & 0.002 & 0.0123 & 0.005 & 0.0052 & 0.0021 \\
\hline
\end{tabular}

Harike Wetland (Table 14) Liver PUFAs, during the present study period, showed significant positive relationship with $\mathrm{Cd}$ (0.7287) and $\mathrm{Pb}(1.7948)$ and significant negative relationship with As (-0.9574), Co (-0.9976) and Zn (-0.7287). Liver SFAs showed significant positive relationship with intestine PUFAs (0.9994) and As (0.6592) and significant negative relationship with intestine SFAs $(-0.9357), \mathrm{Cr}(-0.9862)$ and $\mathrm{Pb}(-3.6489)$. Intestine PUFAs showed, significant positive relationship with As (0.6847) and Co (0.5049) and significant negative relationship with intestine SFAs $(-0.9230)$, $\mathrm{Cr}(-0.9800), \mathrm{Fe}(-0.612435)$ and $\mathrm{Pb}(-3.5742)$. Intestine SFAs showed significant positive relationship with B
(0.8865), $\mathrm{Cr}$ (0.9811), $\mathrm{Cu}(0.8538), \mathrm{Fe}(0.8693)$ and $\mathrm{Ni}$ $(0.822728)$ and significant negative relationship with $\mathrm{Cd}$ $(-0.6347)$ and $\mathrm{Pb}(-1.0960)$. As represented significant positive relationship with Co (0.9748) and $\mathrm{Mn}(0.4065)$ and significant negative relationship with $\mathrm{Cr}(-0.5260)$ and $\mathrm{Pb}$ $(-7.43415)$. B showed significant positive relationship with $\mathrm{Cr}$ (0.7804), Cu (0.9977), Fe (0.9993), Mn (0.9923), Ni (0.9923) and $\mathrm{Zn}(0.9202)$ and significant negative relationship with $\mathrm{Cd}(-0.9202)$ and $\mathrm{Pb}(-4.3227)$. Cd represented significant negative relationship with all the metals except $\mathrm{Pb}$ (2.0443). Co showed significant positive relationship with $\mathrm{Mn}(0.600)$ and $\mathrm{Zn}(0.6805)$ and significant negative

Table 7 Heavy metal pollution index (HPI) of Harike Wetland during June 2018 to February 2019

\begin{tabular}{|c|c|c|c|c|c|c|c|}
\hline $\begin{array}{l}\text { Heavy } \\
\text { metals }\end{array}$ & $\begin{array}{l}\text { Mean } \pm \text { S.D of all the } \\
\text { seasons }\end{array}$ & $\begin{array}{l}\text { WHO permissible } \\
\text { limits }(\mathrm{mg} / \mathrm{l})\end{array}$ & $\begin{array}{l}\text { Mean concentration } \\
\mu \mathrm{g} / \mathrm{l}(V i)\end{array}$ & $\begin{array}{l}\text { Highest permitted value } \\
\mu \mathrm{g} / \mathrm{l}(\mathrm{Si})\end{array}$ & $\begin{array}{l}\text { Unit } \\
\text { weightage } \\
(W i)\end{array}$ & Qi & $\Sigma \mathrm{Wi} \times \mathrm{Qi}$ \\
\hline As & $0.0122 \pm 0.004$ & 0.01 & 12.2 & 10 & 0.1 & 122 & 12.2 \\
\hline B & $0.0767 \pm 0.057$ & 2.4 & 76.7 & 2400 & 0.0004 & 3.195 & 0.001278 \\
\hline Cd & $0.0104 \pm 0.001$ & 0.005 & 10.4 & 5 & 0.2 & 208 & 41.6 \\
\hline Co & $0.0062 \pm 0.002$ & 0.1 & 0.62 & 100 & 0.01 & 0.62 & 0.0062 \\
\hline $\mathrm{Cr}$ & $0.0175 \pm 0.005$ & 0.05 & 17.1 & 50 & 0.02 & 34.2 & 0.684 \\
\hline $\mathrm{Cu}$ & $0.0313 \pm 0.030$ & 2 & 31.3 & 2000 & 0.0005 & 1.565 & 0.0007825 \\
\hline $\mathrm{Fe}$ & $0.0152 \pm 0.005$ & 1 & 15.2 & 300 & 0.003 & 5.066 & 0.015198 \\
\hline Mn & $0.0059 \pm 0.001$ & 0.4 & 5.9 & 400 & 0.002 & 1.475 & 0.00295 \\
\hline $\mathrm{Ni}$ & $0.0158 \pm 0.004$ & 0.02 & 15.8 & 20 & 0.05 & 79 & 3.95 \\
\hline $\mathbf{P b}$ & $0.0108 \pm 0.001$ & 0.05 & 10.8 & 50 & 0.02 & 21.6 & 0.432 \\
\hline $\mathrm{Zn}$ & $0.0075 \pm 0.004$ & 3 & 7.5 & 3000 & $\begin{array}{l}0.0003 \\
\boldsymbol{\Sigma}_{\mathbf{W i}}=\mathbf{0 . 4 0 6 2}\end{array}$ & 0.25 & $\begin{array}{l}0.00075 \\
\boldsymbol{\Sigma}_{\mathbf{W i Q i}}=\mathbf{5 8 . 8 9 2 4}\end{array}$ \\
\hline HPI = & $V_{i} Q_{i} / \Sigma_{W i}=144.98$ & & & & & & \\
\hline
\end{tabular}


Table 8 Heavy metal pollution index (HPI) of Nangal Wetland during June 2018 to February 2019

\begin{tabular}{|c|c|c|c|c|c|c|c|}
\hline Heavy metals & $\begin{array}{l}\text { Mean } \pm \text { S.D of all } \\
\text { the seasons }\end{array}$ & $\begin{array}{l}\text { WHO permissible } \\
\text { limits }(\mathrm{mg} / \mathrm{l})\end{array}$ & Mean concentration $\mu \mathrm{g} / \mathrm{l}(\mathrm{Vi})$ & $\begin{array}{l}\text { Highest permitted } \\
\text { value } \mu \mathrm{g} / \mathrm{l}(\mathrm{Si})\end{array}$ & Unit weightage (Wi) & Qi & $\Sigma \mathrm{Wi} \times \mathrm{Qi}$ \\
\hline As & $0.0002 \pm 0.0001$ & 0.01 & 0.2 & 10 & 0.1 & 2 & 0.2 \\
\hline B & $0.0387 \pm 0.0165$ & 2.4 & 38.7 & 2400 & 0.0004 & 1.612 & 0.00064 \\
\hline Cd & $0.00018 \pm 0.00$ & 0.005 & 0.18 & 5 & 0.2 & 3.6 & 0.72 \\
\hline Co & $0.0076 \pm 0.004$ & 0.1 & 7.6 & 100 & 0.01 & 7.6 & 0.076 \\
\hline $\mathrm{Cr}$ & $0.0041 \pm 0.0018$ & 0.05 & 1 & 50 & 0.02 & 2.0 & 0.04 \\
\hline $\mathbf{C u}$ & $0.0311 \pm 0.030$ & 2 & 31.1 & 2000 & 0.0005 & 1.555 & 0.00077 \\
\hline $\mathrm{Fe}$ & $0.0075 \pm 0.004$ & 1 & 7.5 & 300 & 0.003 & 2.5 & 0.0075 \\
\hline Mn & $0.0059 \pm 0.0013$ & 0.4 & 5.9 & 400 & 0.002 & 1.475 & 0.00295 \\
\hline $\mathrm{Zn}$ & $0.0014 \pm 0.00$ & 3 & 1.4 & 3000 & $\begin{array}{l}0.0003 \\
\boldsymbol{\Sigma}_{\mathbf{W i}}=\mathbf{0 . 3 3 6 2}\end{array}$ & 0.046 & $\begin{array}{l}0.00138 \\
\boldsymbol{\Sigma}_{\mathbf{W i Q i}}=\mathbf{1 . 0 4 9 2 4}\end{array}$ \\
\hline
\end{tabular}

relationship with $\mathrm{Pb}$ (-4.5122). Cr showed significant positive relationship with $\mathrm{Cu}(0.7370), \mathrm{Fe}(0.7574)$ and $\mathrm{Ni}(0.6973)$ and significant negative relationship with $\mathrm{Pb}(-4.3021) . \mathrm{Cu}$ showed significant positive relationship with $\mathrm{Fe}(0.9995), \mathrm{Mn}$ (0.9735), $\mathrm{Ni}(0.9983)$ and $\mathrm{Zn}(0.9442)$ and significant negative relationship with $\mathrm{Pb}(-5.0967)$. Fe showed significant negative relationship only with $\mathrm{Pb}(-6.9943)$. Mn showed significant positive relationship with $\mathrm{Ni}(0.9849)$ and $\mathrm{Zn}$ (0.9945) and significant negative relationship with $\mathrm{Pb}$ $(-3.3698)$. Ni showed significant positive relationship with $\mathrm{Zn} \mathrm{(0.9614)} \mathrm{and} \mathrm{significant} \mathrm{negative} \mathrm{relationship} \mathrm{with} \mathrm{Pb}$ $(-4.5801)$. Pb showed significant negative relationship with $\mathrm{Zn}(-8.6382)$.

\section{Fatty acid (FA) profile of different tissues}

Three major groups of FAs, viz. PUFAs, MUFAs and SFAs, have been identified in the liver and intestine of Labeo rohita of the test fish sample in comparison with the control fish samples.

\section{FA profile of the liver}

PUFAs During the present course of the study period, among the n-3 PUFAs, linolenic acid in the liver of control fish sample shows significant difference $(p<0.05)$ during rainy season and found to be comparable during autumn and winter

Table 9 Categorization of heavy metal pollution index (Edet and Offiong 2002; Giri and Singh 2014)

\begin{tabular}{lll}
\hline MI & HPI & Class \\
\hline$<15$ & Low & I \\
$15-30$ & Medium & II \\
$30>$ & High & III \\
\hline
\end{tabular}

seasons. In test fish sample, Lin acid was absent in the liver during autumn and winter seasons. EPA was significantly higher $(p<0.05)$ in the winter season of control as well as in the test fish samples. EPA and DHA differ significantly in all the seasons of fish samples from both the sampling sites. Among the n- 6 fatty acids, linoleic acid, arachidonic acid and eicosenoic acid were found to be significantly higher in the control fish samples as compared to those in the test fish samples during all the seasons. The mean total n-3 and $\mathrm{n}-6$ PUFAs in the liver tissue were declined in the test fish samples as compared to control fish samples except in winter season (Table 15).

Season-wise results in the control fish samples showed that minimum level of linolenic acid, EPA, docosapentaenoic acid (DPA), DHA, total n-3 PUFAs linoleic acid, AA, eicosenoic acid (ENA), eicosadecanoic acid (EDA) and total n-6 PUFAs were found during autumn $(0.02 \%)$, rainy $(8.40 \%)$, autumn $(2.08 \%)$, rainy $(2.16 \%)$, autumn $(22.65 \%)$, rainy $(0.01 \%)$, autumn $(0.05 \%)$, rainy $(4.33 \%)$, autumn $(0.06 \%)$ and winter $(13.50 \%)$ seasons, respectively, in the present study. In our findings, maximum values of linolenic acid (Lin), EPA, DPA, DHA, total n-3 PUFAs linoleic acid (Len), AA, ENA, EDA and total n-6 PUFAs were recorded during rainy $(7.72 \%)$, winter $(19.74 \%)$, rainy $(26.62 \%)$, winter $(24.47 \%)$, rainy $(44.92 \%)$, autumn $(4.04 \%)$, winter $(7.51 \%)$, autumn $(7.02 \%)$, rainy $(2.13 \%)$ and rainy $(13.63 \%)$ seasons, respectively. The mean minimum $(34.12 \%)$ and maximum $(58.56 \%)$ of total PUFAs were recorded during autumn and rainy season, respectively. Significant difference $(p<0.05)$ was observed in all the fatty acids during all the three seasons except Lin (autumn and winter) and total n-3 PUFAs and AA (rainy and winter). Total n-6 PUFAs were found to be comparable during all the seasons of control fish sample during the present study period. 
Table 10 Metal index (MI) of Harike Wetland during June 2018 to February 2019

\begin{tabular}{llll}
\hline Heavy metals & $\begin{array}{l}\text { Mean concentration } \\
\mu \mathrm{g} / \mathrm{l}(\mathrm{Vi})\end{array}$ & $\begin{array}{l}\text { Highest permitted } \\
\text { value } \mu \mathrm{g} / \mathrm{l}(\mathrm{Si})\end{array}$ & $\mathrm{MI}$ \\
\hline As & 12.2 & 10 & 1.22 \\
$\mathbf{B}$ & 76.7 & 2400 & 0.03195 \\
$\mathbf{C d}$ & 10.4 & 5 & 2.08 \\
$\mathbf{C o}$ & 0.62 & 100 & 0.0062 \\
$\mathbf{C r}$ & 17.1 & 50 & 0.342 \\
$\mathbf{C u}$ & 31.3 & 2000 & 0.01565 \\
$\mathbf{F e}$ & 15.2 & 300 & 0.0506 \\
$\mathbf{M n}$ & 5.9 & 400 & 0.01475 \\
$\mathbf{N i}$ & 15.8 & 20 & 0.79 \\
$\mathbf{P b}$ & 10.8 & 50 & 0.216 \\
$\mathbf{Z n}$ & 7.5 & 3000 & 0.0025 \\
& & & $\mathbf{M I}=\mathbf{4 . 7 6 9}$
\end{tabular}

Saturated fatty acids (SFAs) Data on SFAs recorded during the present study period in the liver of Labeo rohita collected from Nangal Wetland (control site) and Harike Wetland (polluted site) during different seasons are shown in Table 16. Myristic acid, palmitic acid, eicosanoic acid (except rainy and winter), octadecanoic acid, undecylic acid, pentadecylic acid and margaric acid in the control fish liver differ significantly $(p<0.05)$ during three seasons. In the test fish samples, palmitic acid was absent in all the seasons. In myristic acid, stearic acid, eicosanoic acid (except rainy and winter), undecylic acid and pentadecylic acid, significant $(p<0.05)$ difference exists during rainy, autumn and winter seasons. Total SFAs were found to decline significantly $(p<0.05)$ in the liver of test fish sample as compared to control fish sample during autumn and winter seasons.

Table 11 Metal index (MI) of Nangal Wetland during June 2018 to February 2019

\begin{tabular}{llll}
\hline Heavy metals & $\begin{array}{l}\text { Mean concentration } \\
\mu \mathrm{g} / \mathrm{l}(\mathrm{Vi})\end{array}$ & $\begin{array}{l}\text { Highest permitted } \\
\text { value } \mu \mathrm{g} / \mathrm{l}(\mathrm{Si})\end{array}$ & $\mathrm{MI}$ \\
\hline $\mathbf{A s}$ & 0.2 & 10 & 0.02 \\
$\mathbf{B}$ & 38.7 & 2400 & 0.0161 \\
$\mathbf{C d}$ & 0.18 & 5 & 0.036 \\
$\mathbf{C o}$ & 7.6 & 100 & 0.076 \\
$\mathbf{C r}$ & 1 & 50 & 0.02 \\
$\mathbf{C u}$ & 31.1 & 2000 & 0.0155 \\
$\mathbf{F e}$ & 7.5 & 300 & 0.025 \\
$\mathbf{M n}$ & 5.9 & 400 & 0.0147 \\
$\mathbf{Z n}$ & 1.4 & 3000 & 0.000466 \\
& & & $\mathbf{M I}=\mathbf{0 . 2 2 3 7}$ \\
\hline
\end{tabular}

Table 12 Water quality characteristics using metal index (Sulochana 2016)

\begin{tabular}{lll}
\hline MI & Characteristics & Class \\
\hline$<0.3$ & Very pure & I \\
$0.3-1.0$ & Pure & II \\
$1.0-2.0$ & Slightly affected & III \\
$2.0-4.0$ & Moderately affected & IV \\
$4.0-6.0$ & Strongly affected & V \\
$>6.0$ & Seriously affected & VI \\
\hline
\end{tabular}

Minimum levels of myristic acid, palmitic acid, stearic acid, eicosanoic acid, octadecanoic acid, undecylic acid, pentadecylic acid and margaric acid in the control fish liver were recorded during autumn $(0.01 \%)$, rainy $(0.01 \%)$, autumn $(0.01 \%)$, autumn $(0.70 \%)$, winter $(1.04 \%)$, winter $(5.19 \%)$, rainy $(4.42 \%)$, rainy $(5.08 \%)$ and winter $(0.88 \%)$ seasons, respectively. Maximum levels of myristic acid, palmitic acid, stearic acid, eicosanoic acid, octadecanoic acid, undecylic acid, pentadecylic acid and margaric acids were observed during winter $(0.05 \%)$, autumn $(0.09 \%)$, rainy $(0.33 \%)$, winter $(3.22 \%)$, rainy $(10.46 \%)$, autumn $(8.56 \%)$, winter $(16.89 \%)$, autumn $(40.93 \%)$ and rainy (11.08\%) seasons, respectively. Differences in stearic acid and capric acid were statistically nonsignificant $(p>0.05)$ in all the seasons of control fish liver.

Major groups of FAs such as PUFAs and SFAs from the liver tissue of fish collected from the different habitats in the similar seasons showed decline of FAs in the sample taken from polluted site (Figures 3 and 4).

\section{FA profile of the intestine}

PUFAs Among the n-3 PUFAs, Lin. was present during autumn season in the intestine of control fish samples. In the test fish sample, Lin. was absent in all the seasons except rainy season. EPA was significantly $(p<0.05)$ higher in the autumn season of control and during the winter season of test fish sample. EPA and DPA show significant difference in all the seasons in case of control fish samples; however, nonsignificant $(p>0.05)$ trend was observed in case of test fish samples. Among n-6 FAs, AA was found to be significantly higher in the control fish samples during rainy and winter seasons. EDA was also found to be significantly higher $(p<0.05)$ in the intestine of control fish samples. The mean total n-3 PUFAs were declined significantly in test fish sample in all the seasons (except winter) as compared to control fish samples. In case of total n-6 PUFAs, significant decline in these FAs was also observed in test fish samples in all the seasons (except rainy) when compared with control fish samples (Table 17).

Season-wise results in the control fish samples concluded that minimum levels of EPA, DPA, DHA, total n-3 PUFAs Len, AA, ENA, EDA acid and total n-6 PUFAs were found during winter $(6.72 \%)$, autumn $(10.32 \%)$, winter $(3.82 \%)$, 
Table 13 Pearson's correlation matrix among various heavy metals in water with respect to major groups of fatty acids in liver and intestine of Labeo rohita (Hamilton) collected from Nangal Wetland

\begin{tabular}{|c|c|c|c|c|c|c|c|c|c|c|c|c|c|}
\hline & $\begin{array}{l}\text { Liver } \\
\text { PUFA }\end{array}$ & $\begin{array}{l}\text { Liver } \\
\text { SFA }\end{array}$ & $\begin{array}{l}\text { Intestine } \\
\text { PUFA }\end{array}$ & $\begin{array}{l}\text { Intestine } \\
\text { SFA }\end{array}$ & As & $\mathrm{B}$ & $\mathrm{Cd}$ & $\mathrm{Co}$ & $\mathrm{Cr}$ & $\mathrm{Cu}$ & $\mathrm{Fe}$ & $\mathrm{Mn}$ & $\mathrm{Zn}$ \\
\hline Liver PUFA & 0 & & & & & & & & & & & & \\
\hline Liver SFA & -0.98747 & 0 & & & & & & & & & & & \\
\hline $\begin{array}{l}\text { Intestine } \\
\text { PUFA }\end{array}$ & -0.47818 & 0.610774 & 0 & & & & & & & & & & \\
\hline Intestine SFA & 0.557422 & -0.68145 & -0.99571 & 0 & & & & & & & & & \\
\hline As & -0.83886 & 0.74245 & -0.07696 & -0.01566 & 0 & & & & & & & & \\
\hline B & -0.56201 & 0.685492 & 0.995178 & -0.99998 & 0.021202 & 0 & & & & & & & \\
\hline $\mathrm{Cd}$ & -0.26782 & 0.416502 & 0.974246 & -0.94919 & -0.2998 & 0.947432 & 0 & & & & & & \\
\hline Co & -0.99954 & 0.991796 & 0.504543 & -0.5823 & 0.821995 & 0.586795 & 0.296866 & 0 & & & & & \\
\hline $\mathrm{Cr}$ & -0.6337 & 0.503693 & -0.37638 & 0.289007 & 0.952683 & -0.2837 & -0.5756 & 0.609994 & 0 & & & & \\
\hline $\mathrm{Cu}$ & -0.955 & 0.896226 & 0.196149 & -0.28608 & 0.96257 & 0.291382 & -0.03001 & 0.94558 & 0.834639 & 0 & & & \\
\hline $\mathrm{Fe}$ & 0.525987 & 0.991796 & 0.495443 & -0.41291 & -0.90419 & 0.407854 & 0.678551 & -0.5 & -0.99124 & -0.75459 & 0 & & \\
\hline $\mathrm{Mn}$ & -0.99954 & 0.991796 & 0.504543 & -0.5823 & 0.821995 & 0.586795 & 0.296866 & 1 & 1 & 0.94558 & -0.5 & 0 & \\
\hline $\mathrm{Zn}$ & 0.525987 & -0.38519 & 0.495443 & -0.41291 & -0.90419 & 0.407854 & 0.678551 & -0.5 & -0.99124 & -0.75459 & 1 & -0.5 & 0 \\
\hline
\end{tabular}

winter $(10.55 \%)$, rainy $(0.03 \%)$, autumn $(1.40 \%)$, winter $(1.82 \%)$, rainy $(0.11 \%)$ and winter $(3.88 \%)$ seasons, respectively. Maximum levels of EPA, DPA, DHA, total n-3 PUFAs AA, ENA, EDA and total n-6 PUFAs were observed during autumn $(19.09 \%)$, rainy $(26.66 \%)$, autumn $(8.95 \%)$, rainy $(42.13 \%)$, autumn $(0.83 \%)$, rainy $(6.93 \%)$, autumn $(6.01 \%)$, autumn $(5.84 \%)$ and autumn (14.09\%) seasons, respectively. The mean minimum (14.43\%) and maximum $(54.11 \%)$ total PUFAs were recorded during winter and autumn seasons, respectively. Nonsignificant difference $(p>0.05)$ was observed in all the seasons of Len, ENA (except winter), AA (except rainy) and DHA (except autumn season). Total n-6 PUFAs was found to differ significantly $(p<0.05)$ during all the seasons of control fish samples (Table 17).

Saturated fatty acids (SFAs) Data on SFAs related to the intestine of Labeo rohita collected from Nangal Wetland (control site) and Harike Wetland (polluted site) during different seasons is shown in Table 18. Values of myristic acid (except winter), palmitic acid, stearic acid, octadecanoic acid, undecylic acid, pentadecylic acid and margaric acid (except rainy) in the control fish intestine differ significantly $(p<0.05)$ during all the seasons. Eicosanoic acid showed nonsignificant $(p>0.05)$ difference in three seasons. Total SFAs were found to increase in the intestine of test fish samples as compared to control fish samples during rainy, autumn and winter seasons.

Minimum levels of myristic acid, palmitic acid, stearic acid, eicosanoic acid, octadecanoic acid, capric acid, undecylic acid, pentadecylic acid and margaric acid in the control fish intestine were recorded during rainy $(0.66 \%)$, autumn $(0.82 \%)$, autumn $(0.21 \%)$, winter $(0.16 \%)$, winter $(0.29 \%)$, rainy $(0.92 \%)$, rainy $(3.02 \%)$, rainy $(0.14 \%)$ and winter $(11.56 \%)$ seasons, respectively. Maximum values of myristic acid, palmitic acid, stearic acid, eicosanoic acid, octadecanoic acid, capric acid, undecylic acid, pentadecylic acid and margaric acid were found during winter (1.33\%), rainy $(1.93 \%)$, rainy $(0.62 \%)$, autumn $(0.31 \%)$, autumn $(17.59 \%)$, autumn $(5.51 \%)$, autumn $(12.96 \%)$, winter $(41.64 \%)$ and rainy $(40.60 \%)$ season, respectively. Difference in eicosanoic acid, myristic acid (except winter) and capric acid (except winter) were statistically nonsignificant $(p>0.05)$ in all the seasons of control fish intestine (Table 18).

Major groups of fatty acids such as PUFAs and SFAs from the intestine tissue of fish collected from different habitats in the similar seasons showed decline of FAs in the sample taken from polluted site (Figures 5 and 6).

\section{Discussion}

Due to their existence in different trophic levels, mainly of its size, age and mode of nutrition, nowadays fish are used as a bioindicator for diverse organic and inorganic pollutants in freshwater ecosystems (Borga et al. 2004; Tashla et al. 2018). To gain the advantageous effects of their natural cleansing capacity for absorption of various pollutants including pesticides and heavy metals, numerous wetlands have been utilized (Joyce 2012). Plenty of contaminants that mount up through natural and human activities enter via water in wetland sediments and plants available there (Li et al. 2006; Adekola and Eletta 2007; Lu et al. 2011; Almuktar et al. 2018). Massive amount of wastes along with synthetic chemicals are generated due to industrial activities and recent development and discharged directly into wetlands without any treatment; because of their fast growth and high biomass, aquatic plants uptake most of these pollutants through root and shoot structures (Bonanno and Giudice 2010; Matache et al. 2013; Bashir et al. 2020). Translocation of heavy metals to shoot is restricted, but exaggeration of heavy metals in roots reaches as high as 100,000 times more than the surrounding 


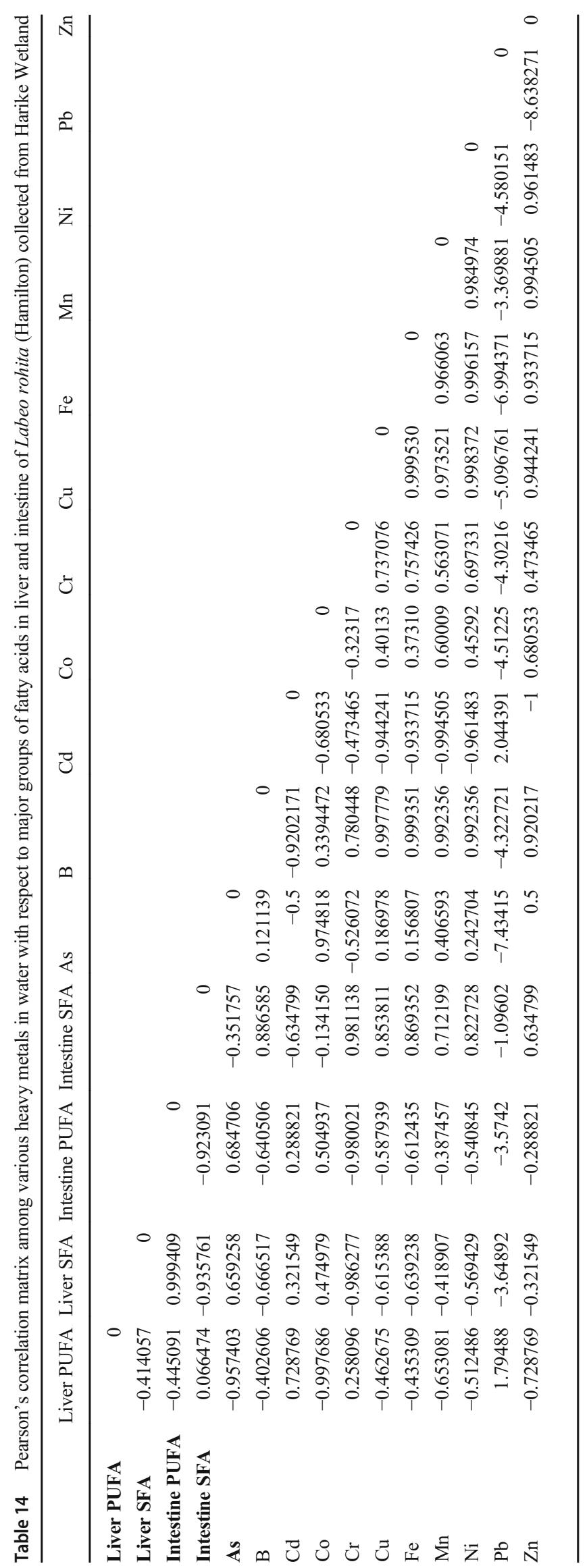


Table 15 Polyunsaturated fatty acids (\%) in the liver of Labeo rohita collected from Nangal Wetland (control site) and Harike Wetland (polluted site) during different seasons

\begin{tabular}{|c|c|c|c|c|c|c|}
\hline \multirow{2}{*}{$\begin{array}{l}\text { Sites } \\
\text { Seasons }\end{array}$} & \multicolumn{3}{|c|}{ Nangal Wetland (control site) } & \multicolumn{3}{|c|}{ Harike Wetland (polluted site) } \\
\hline & Rainy & Autumn & Winter & Rainy & Autumn & Winter \\
\hline Linolenic acid (C18:3 n-3) & $7.72 \pm 3.83^{\mathrm{b}}$ & $0.02 \pm 0.00^{\mathrm{a}}$ & $0.02 \pm 0.00^{\mathrm{a}}$ & $0.45 \pm 0.00^{\mathrm{a}}$ & NIL & NIL \\
\hline Eicosapentaenoicacid (C20:5 n-3) & $8.40 \pm 1.27^{\mathrm{a}}$ & $16.11 \pm 0.53^{\mathrm{b}}$ & $19.74 \pm 0.40^{\mathrm{c}}$ & $15.92 \pm 5.60^{\mathrm{b}}$ & $9.76 \pm 1.00^{\mathrm{a}}$ & $43.99 \pm 4.31^{\mathrm{c}}$ \\
\hline Docosapentaenoic acid (C22:5 n-3) & $26.62 \pm 2.56^{\mathrm{c}}$ & $2.08 \pm 0.91^{\mathrm{b}}$ & $0.01 \pm 0.00^{\mathrm{a}}$ & $0.01 \pm 0.00^{\mathrm{a}}$ & $5.11 \pm 1.48^{\mathrm{b}}$ & $0.48 \pm 0.17^{\mathrm{a}}$ \\
\hline Docosahexaenoic acid (C22:6 n-3) & $2.16 \pm 1.31^{\mathrm{a}}$ & $4.45 \pm 0.14^{\mathrm{c}}$ & $24.47 \pm 0.31^{\mathrm{b}}$ & $17.56 \pm 4.52^{\mathrm{c}}$ & $0.72 \pm 0.55^{\mathrm{a}}$ & $8.88 \pm 1.21^{\mathrm{b}}$ \\
\hline Total n-3 PUFAs & $44.92 \pm 1.31^{\mathrm{b}}$ & $22.65 \pm 1.46^{\mathrm{a}}$ & $44.22 \pm 0.26^{\mathrm{b}}$ & $33.94 \pm 5.19^{\mathrm{b}}$ & $15.27 \pm 0.37^{\mathrm{a}}$ & $53.48 \pm 3.15^{\mathrm{c}}$ \\
\hline \multicolumn{7}{|l|}{ n-6 PUFAs } \\
\hline Linoleic acid (C18:2 n-6) & $0.01 \pm 0.00^{\mathrm{a}}$ & $4.04 \pm 2.02^{\mathrm{b}}$ & $0.01 \pm 0.00^{\mathrm{a}}$ & $0.01 \pm 0.00^{\mathrm{a}}$ & $0.66 \pm 0.33^{\mathrm{b}}$ & $0.01 \pm 0.00^{\mathrm{a}}$ \\
\hline Arachidonic acid (C20:4 n-6) & $7.19 \pm 0.33^{\mathrm{b}}$ & $0.05 \pm 0.01^{\mathrm{a}}$ & $7.51 \pm 0.81^{\mathrm{b}}$ & $0.03 \pm 0.00^{\mathrm{a}}$ & $0.08 \pm 0.01^{\mathrm{a}}$ & $4.25 \pm 1.37^{\mathrm{b}}$ \\
\hline Eicosenoic acid & $4.33 \pm 0.79^{\mathrm{a}}$ & $7.02 \pm 1.42^{\mathrm{b}}$ & $5.19 \pm 0.48^{\mathrm{ab}}$ & $0.01 \pm 0.00^{\mathrm{a}}$ & $2.56 \pm 0.29^{\mathrm{b}}$ & $6.57 \pm 0.50^{\mathrm{c}}$ \\
\hline Eicosadecanoic acid & $2.13 \pm 0.05^{\mathrm{c}}$ & $0.06 \pm 0.05^{\mathrm{a}}$ & $0.78 \pm 0.39^{\mathrm{b}}$ & $0.03 \pm 0.00^{\mathrm{a}}$ & $1.02 \pm 0.95^{\mathrm{ab}}$ & $2.70 \pm 1.20^{\mathrm{b}}$ \\
\hline Total n-6 PUFAs & $13.63 \pm 0.73^{\mathrm{a}}$ & $11.46 \pm 3.05^{\mathrm{a}}$ & $13.50 \pm 0.74^{\mathrm{a}}$ & $0.08 \pm 0.00^{\mathrm{a}}$ & $4.66 \pm 0.26^{\mathrm{b}}$ & $13.53 \pm 2.06^{\mathrm{c}}$ \\
\hline n-3/n-6 ratio & $3.32 \pm 0.28^{\mathrm{a}}$ & $2.55 \pm 1.10^{\mathrm{a}}$ & $3.28 \pm 0.17^{\mathrm{a}}$ & $0.03 \pm 0.00^{\mathrm{a}}$ & $3.28 \pm 0.14^{\mathrm{b}}$ & $4.08 \pm 0.46^{\mathrm{c}}$ \\
\hline Total PUFAs & $58.56 \pm 0.62^{\mathrm{b}}$ & $34.12 \pm 0.92^{\mathrm{a}}$ & $57.72 \pm 0.92^{\mathrm{b}}$ & $33.94 \pm 5.19^{\mathrm{b}}$ & $19.94 \pm 0.57^{\mathrm{a}}$ & $67.14 \pm 5.28^{\mathrm{c}}$ \\
\hline
\end{tabular}

Only major PUFAs have been included; values are mean \pm S.E. Values with same superscript in a row with respect to one sampling site during different seasons do not differ significantly $(p>0.05)$

aquatic environment (Mishra et al. 2008; Page and Feller 2015). Fishes feed on phytoplankton, zooplankton and aquatic plants and came into direct contact with wetland pollution all over the world, resultantly well considered to be the indicator of pollution (Zayed et al. 1998; Zhu et al. 1999; Kamal et al. 2004; Souza et al. 2013). In the Indus River, depletion of zooplankton, phytoplankton and fatty acid composition of fishes has been observed due to the presence of high level of sulphates, phenols, heavy metals and total dissolved solids at the collection site (Mahboob et al. 2019).

During the present course of the study, poor water quality of Harike Wetland as compared to control site was observed to be affected by industrial effluent discharge from Harike Wetland which results in variation in the water quality parameters. The average results of these parameters were compared with ISI (1973), ICMR (1975) and WHO (1992). On the basis of WQI and on comparing the physico-chemical parameters with national and international standards, it could be summarized that water quality of Harike Wetland is "poor" due to the presence of industrial effluents and domestic sewage from nearby cities. In perpetuity, if not given proper attention on time, poor quality of water can have deleterious effect on its ecology. In another study, values of WQI are found to be higher than reported by Brraich and Saini (2015) and lower than Akhter and Brraich (2020). In this study, HPI and metal index analysis for Harike Wetland was found to be 144.98 and 4.769 , respectively, indicating that this wetland is seriously affected by pollutants with respect to heavy metals. The results of the indices that the HPI for all the metals were above the critical limit of 100 proposed for drinking water by Prasad and Bose (2001). In another research, lower HPI values were observed (Brraich and Jangu 2015a; Dede 2016; Sahoo and Swain 2020).

At the present studied site, in the liver of control fish sample, mean minimum $(34.12 \%)$ and maximum $(58.56 \%)$ of total PUFAs were recorded during autumn and rainy season, respectively. However, in the liver of test fish sample, mean minimum (19.94\%) and maximum (67.14\%) of total PUFAs were recorded during autumn and winter season, respectively. Data on SFAs recorded during the present study period in the liver of fish collected from control site showed mean minimum $(35.85 \%)$ and maximum $(70.79 \%)$ of total SFAs were recorded during winter and autumn season, respectively. In the liver of test fish sample, mean minimum (28.65\%) and maximum $(88.87 \%$ ) of total SFAs were detected during winter and rainy season, respectively. In another research, it was reported that total lipid amount varies widely during the year (30-50\%) and the maximum level appeared from July to October. The fatty acids observed in liver were myristic $(0.87 \%)$, palmitic $(20.82 \%)$, stearic $(8.87 \%)$, oleic $(7.60 \%)$, linoleic $(1.20 \%)$, EPA (12.40\%) and DHA (31.19\%) in January. The values recorded of total SFAs, total MUFAs and total PUFAs were $31.88 \%, 11.05 \%$ and $45.55 \%$, respectively, in the similar month. PUFA percentage was highest in winter, whereas in autumn its value was minimal. In case of SFAs, the pattern was opposite (Salah and Saloua 2010). However, total SFAs $(31.82 \pm 2.78 \%)$, total n-6 PUFAs $(13.01 \pm 0.77 \%)$, total $n-3$ PUFAs $(36.46 \pm 4.08 \%)$ and $n-3 / n-6$ ratio $(3.7 \pm 0.46 \%)$ were found to be significantly higher in the liver of wild perch (Łuczyńska et al. 2016). 
Table 16 Saturated fatty acids (\%) in the liver of Labeo rohita collected from Nangal Wetland (control site) and Harike Wetland (polluted site) during different seasons

\begin{tabular}{|c|c|c|c|c|c|c|}
\hline \multirow{2}{*}{$\begin{array}{l}\text { Sites } \\
\text { Seasons }\end{array}$} & \multicolumn{3}{|c|}{ Nangal Wetland (control site) } & \multicolumn{3}{|c|}{ Harike Wetland (polluted site) } \\
\hline & Rainy & Autumn & Winter & Rainy & Autumn & Winter \\
\hline Myristic acid (C14:0) & $0.12 \pm 0.04^{\mathrm{b}}$ & $0.01 \pm 0.00^{\mathrm{a}}$ & $0.05 \pm 0.02^{\mathrm{ab}}$ & $0.20 \pm 0.11^{\mathrm{b}}$ & $0.01 \pm 0.00^{\mathrm{a}}$ & $0.07 \pm 0.03^{\mathrm{ab}}$ \\
\hline Palmitic acid (C16:0) & $0.01 \pm 0.00^{\mathrm{a}}$ & $0.09 \pm 0.04^{\mathrm{b}}$ & $0.08 \pm 0.00^{\mathrm{b}}$ & NIL & NIL & NIL \\
\hline Stearic acid (C18:0) & $0.33 \pm 0.28^{\mathrm{a}}$ & $0.01 \pm 0.00^{\mathrm{a}}$ & $0.02 \pm 0.00^{\mathrm{a}}$ & $1.32 \pm 0.74^{\mathrm{a}}$ & NIL & $0.66 \pm 0.33^{\mathrm{b}}$ \\
\hline Eicosanoic acid & $3.10 \pm 0.42^{\mathrm{b}}$ & $0.70 \pm 0.57^{\mathrm{a}}$ & $3.22 \pm 2.33^{\mathrm{b}}$ & $6.24 \pm 1.56^{\mathrm{a}}$ & $11.08 \pm 0.10^{\mathrm{b}}$ & $3.01 \pm 2.70^{\mathrm{a}}$ \\
\hline Octadecanoic acid & $10.46 \pm 5.20^{\mathrm{b}}$ & $4.70 \pm 2.79^{\mathrm{ab}}$ & $1.04 \pm 0.51^{\mathrm{a}}$ & - & - & $1.56 \pm 0.53^{\mathrm{a}}$ \\
\hline Capric acid (C10:0) & $6.07 \pm 0.75^{\mathrm{a}}$ & $8.56 \pm 3.34^{\mathrm{a}}$ & $5.19 \pm 0.52^{\mathrm{a}}$ & $2.10 \pm 1.10^{\mathrm{b}}$ & $0.41 \pm 0.34^{\mathrm{a}}$ & $2.00 \pm 1.64^{\mathrm{b}}$ \\
\hline Undecylic acid (C11:0) & $4.42 \pm 0.67^{\mathrm{a}}$ & $7.65 \pm 0.05^{\mathrm{b}}$ & $16.89 \pm 0.27^{\mathrm{c}}$ & $9.24 \pm 3.26^{\mathrm{b}}$ & $2.05 \pm 1.41^{\mathrm{a}}$ & $8.41 \pm 3.58^{\mathrm{ab}}$ \\
\hline Pentadecylic & $5.08 \pm 2.76^{\mathrm{a}}$ & $40.93 \pm 1.55^{\mathrm{c}}$ & $10.46 \pm 0.02^{\mathrm{b}}$ & $17.42 \pm 3.87^{\mathrm{b}}$ & $11.44 \pm 1.25^{\mathrm{ab}}$ & $10.21 \pm 2.35^{\mathrm{a}}$ \\
\hline Margaric acid & $11.08 \pm 1.66^{\mathrm{c}}$ & $8.11 \pm 1.13^{\mathrm{b}}$ & $0.88 \pm 0.35^{\mathrm{a}}$ & $2.33 \pm 0.99^{\mathrm{a}}$ & $14.98 \pm 12.47^{\mathrm{b}}$ & $4.06 \pm 1.51^{\mathrm{a}}$ \\
\hline Total SFAs & $40.69 \pm 0.82^{\mathrm{b}}$ & $70.79 \pm 0.37^{\mathrm{c}}$ & $35.85 \pm 0.63^{\mathrm{a}}$ & $88.87 \pm 1.89^{\mathrm{a}}$ & $41.05 \pm 16.04^{\mathrm{a}}$ & $28.65 \pm 0.74^{\mathrm{a}}$ \\
\hline SFAs/PUFAs & $0.69 \pm 0.02^{\mathrm{a}}$ & $2.08 \pm 0.09^{\mathrm{b}}$ & $0.61 \pm 0.00^{\mathrm{a}}$ & $1.17 \pm 0.14^{\mathrm{ab}}$ & $2.04 \pm 0.78^{\mathrm{b}}$ & $0.43 \pm 0.05^{\mathrm{a}}$ \\
\hline
\end{tabular}

Only major SFAs have been included; values are mean + S.E. Values with same superscript in a row with respect to one sampling site during different seasons do not differ significantly $(p>0.05)$

During the present investigation conducted on the PUFAs profile in the intestine of control fish sample, mean minimum (14.43\%) and maximum $(54.11 \%)$ of total PUFAs were recorded during autumn and winter season, respectively, while, in the intestine of test fish sample, mean minimum (22.78\%) and maximum $(38.32 \%)$ of total PUFAs were found during winter and rainy season, respectively. In the SFAs in the intestine of control fish sample, mean minimum $(50.90 \%)$ and maximum $(70.55 \%)$ of total SFAs were recorded during autumn and winter season, respectively; however, mean minimum $(62.78 \%)$ and maximum $(72.69 \%)$ of total SFAs were recorded during rainy and autumn season, respectively, in the intestine of test fish sample. In another study, it was concluded that the principal polyunsaturated fatty acid (PUFA) in the intestine was linoleic acid (18:2n-6). These major PUFAs contributed approximately $75 \%$ and $71 \%$ of total fatty acids for meagre and gilthead sea bream, respectively (Kandyliari et al. 2020). Similarly, total PUFAs varied from 31.58 to

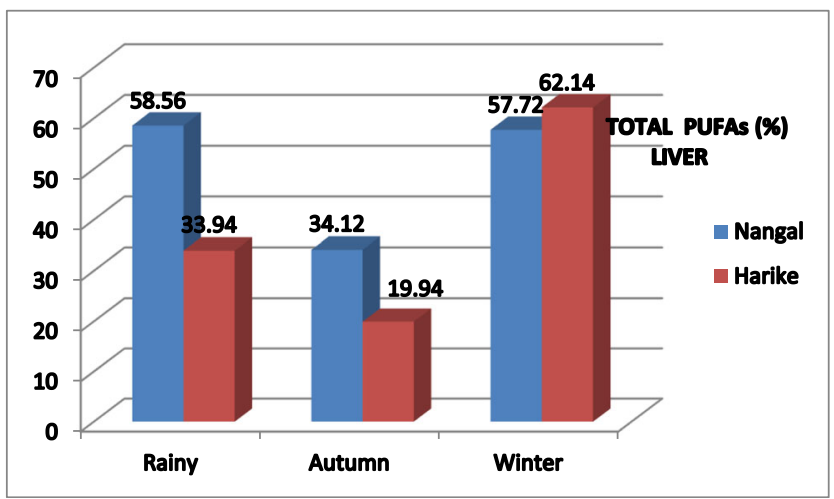

Fig. 3 Total polyunsaturated fatty acid comparison in the liver of fish, Labeo rohita, collected from different habitats in similar seasons
$39.76 \%$ and 3.25 to $4.81 \%$, and total SFAs varied from 32.43 to $47.75 \%$ and 37.42 to $45.04 \%$ in the viscera of Cyprinus carpio and Ctenopharyngodon idella studied under different weight groups (Kaur et al. 2018).

In the present study, a significant $(p<0.05)$ decrease in $\mathrm{n}-3$, $\mathrm{n}-6$ fatty acids and total PUFAs in the liver and intestine (except winter) was recorded in the test fish samples from Harike Wetland during different seasons, when compared to control fish samples from Nangal Wetland. Lin during autumn and winter seasons was absent in the liver of test fish samples. EDA in the intestine of test fish samples during rainy and winter season was found to be absent. The decrease in the production of PUFAs in the liver and intestine of the test fish samples may be due to increased level of metal and other pollutants in the water. Similar findings were observed in another study conducted on Cyprinus carpio, Ctenopharyngodon

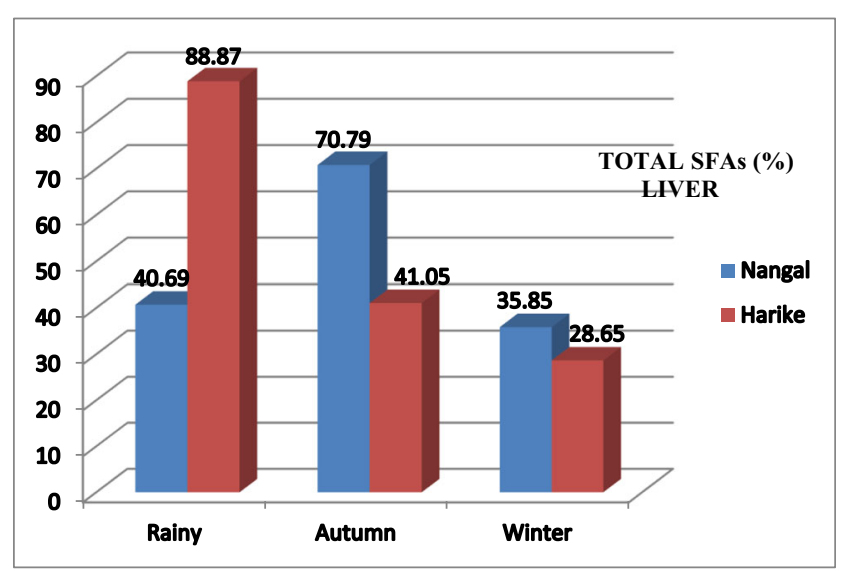

Fig. 4 Total saturated fatty acid comparison in the liver of fish, Labeo rohita, collected from different habitats in similar seasons 
Table 17 Polyunsaturated fatty acids (\%) in the intestine of Labeo rohita collected from Nangal Wetland (control site) and Harike Wetland (polluted site) during different seasons

\begin{tabular}{|c|c|c|c|c|c|c|}
\hline \multirow{2}{*}{$\begin{array}{l}\text { Sites } \\
\text { Seasons }\end{array}$} & \multicolumn{3}{|c|}{ Nangal Wetland (control site) } & \multicolumn{3}{|c|}{ Harike Wetland (polluted site) } \\
\hline & Rainy & Autumn & Winter & Rainy & Autumn & Winter \\
\hline Linolenic acid (C18:3 n-3) & NIL & $3.31 \pm 1.65^{\mathrm{a}}$ & NIL & $0.11 \pm 0.03^{\mathrm{a}}$ & NIL & NIL \\
\hline Eicosapentaenoic acid (C20:5 n-3) & $9.49 \pm 0.16^{\mathrm{b}}$ & $19.09 \pm 0.97^{\mathrm{c}}$ & $6.72 \pm 0.13^{\mathrm{a}}$ & $4.72 \pm 0.93^{\mathrm{a}}$ & $6.60 \pm 0.29^{\mathrm{a}}$ & $8.34 \pm 4.03^{\mathrm{a}}$ \\
\hline Docosapentaenoic acid (C22:5n-3) & $26.66 \pm 4.10^{\mathrm{b}}$ & $10.32 \pm 2.44^{\mathrm{a}}$ & NIL & $9.82 \pm 7.03^{\mathrm{a}}$ & $4.05 \pm 2.10^{\mathrm{a}}$ & $6.56 \pm 3.28^{\mathrm{a}}$ \\
\hline Docosahexaenoic acid (C22:6 n-3) & $5.97 \pm 1.48^{\mathrm{a}}$ & $8.95 \pm 0.76^{\mathrm{b}}$ & $3.82 \pm 0.23^{\mathrm{a}}$ & $5.80 \pm 0.87^{\mathrm{a}}$ & $4.67 \pm 0.84^{\mathrm{a}}$ & $4.44 \pm 1.58^{\mathrm{a}}$ \\
\hline Total n-3 PUFAs & $42.13 \pm 5.25^{\mathrm{b}}$ & $40.02 \pm 0.58^{\mathrm{b}}$ & $10.55 \pm 0.36^{\mathrm{a}}$ & $20.43 \pm 5.25^{\mathrm{a}}$ & $15.33 \pm 1.16^{\mathrm{a}}$ & $20.21 \pm 3.19^{\mathrm{a}}$ \\
\hline \multicolumn{7}{|l|}{ n-6 PUFAs } \\
\hline Linoleic acid (C18:2n-6) & $0.03 \pm 0.00^{\mathrm{a}}$ & $0.83 \pm 0.41^{\mathrm{a}}$ & $0.42 \pm 0.38^{\mathrm{a}}$ & $0.52 \pm 0.24^{\mathrm{a}}$ & $1.67 \pm 1.40^{\mathrm{b}}$ & $1.87 \pm 0.34^{\mathrm{b}}$ \\
\hline Arachidonic acid (C20:4 n-6) & $6.93 \pm 0.46^{\mathrm{b}}$ & $1.40 \pm 0.70^{\mathrm{a}}$ & $2.03 \pm 0.11^{\mathrm{a}}$ & $0.53 \pm 0.24^{\mathrm{b}}$ & $1.68 \pm 1.41^{\mathrm{b}}$ & $1.88 \pm 0.35^{\mathrm{a}}$ \\
\hline Eicosenoic acid & $4.66 \pm 0.74^{\mathrm{a}}$ & $6.01 \pm 3.35^{\mathrm{a}}$ & $1.82 \pm 0.18^{\mathrm{b}}$ & $17.18 \pm 4.28^{\mathrm{c}}$ & $7.94 \pm 3.37^{\mathrm{b}}$ & $0.53 \pm 0.19^{\mathrm{a}}$ \\
\hline Eicosadecanoic acid & $0.11 \pm 0.03^{\mathrm{a}}$ & $5.84 \pm 2.40^{\mathrm{b}}$ & NIL & NIL & $1.31 \pm 0.08^{\mathrm{a}}$ & NIL \\
\hline Total n-6 PUFAs & $11.74 \pm 1.24^{\mathrm{b}}$ & $14.09 \pm 0.17^{\mathrm{c}}$ & $3.88 \pm 0.26^{\mathrm{a}}$ & $17.89 \pm 4.61^{\mathrm{b}}$ & $11.16 \pm 1.65^{\mathrm{b}}$ & $2.57 \pm 0.24^{\mathrm{a}}$ \\
\hline n-3/n-6 Ratio & $3.57 \pm 0.23^{\mathrm{b}}$ & $2.83 \pm 0.00^{\mathrm{a}}$ & $2.72 \pm 0.10^{\mathrm{a}}$ & $1.63 \pm 0.96^{\mathrm{a}}$ & $1.48 \pm 0.38^{\mathrm{a}}$ & $7.76 \pm 0.47^{\mathrm{b}}$ \\
\hline Total PUFAs & $53.87 \pm 6.34^{\mathrm{b}}$ & $54.11 \pm 0.75^{\mathrm{b}}$ & $14.43 \pm 0.63^{\mathrm{a}}$ & $38.32 \pm 0.65^{\mathrm{b}}$ & $26.49 \pm 0.49^{\mathrm{a}}$ & $22.78 \pm 3.43^{\mathrm{a}}$ \\
\hline
\end{tabular}

Only major PUFAs have been included; values are mean \pm S.E. Values with same superscript in a row with respect to one sampling site during different seasons do not differ significantly $(p>0.05)$

idella and Hypophthalmichthys molitrix from highly and low polluted studied sites (Abedi and Sahari 2014).

The maximum percentage of total saturated fatty acids in the liver (rainy) and intestine (autumn), 88.87\% and $72.69 \%$, in test fish samples were recorded, respectively, in the present study. For the movement and to search for food, the fish which is having high concentration of saturated fatty acids needs more energy (Kandemir and Polat 2007). Similar results were recorded in the fish (Mahboob et al. 2019). Similarly during the present course of work, palmitic acid was not recorded in the liver of test fish sample during all the seasons. Lauric acid and stearic acid were also absent in the intestine of test fish samples during autumn season. It is believed that fish samples taken from polluted site adversely affect the composition of fatty acids.

There were quantitative difference between fatty acid composition of liver and intestine during different seasons. In the liver tissue (control), highest (58.56\%) and lowest (34.12\%) amount of total PUFAs were recorded during rainy and autumn seasons, respectively, and highest $(70.79 \%)$ and lowest (35.85\%) values of total SFAs were found during autumn and winter seasons, respectively. In the intestine (control), the highest $(54.11 \%)$ and lowest $(14.43 \%)$ amount of total PUFAs were recorded during autumn and winter seasons. respectively, and highest $(70.55 \%)$ and lowest $(50.90 \%)$ values of total SFAs were found during winter and autumn, respectively. FA composition in various organs of the fish is affected by water temperature, age, sex, species, pollution level, nutritional condition, seasonal variation and origin of fish (Robert et al. 2014; Mellery et al. 2016; Johnston et al.
2020; Zhang et al. 2020). The similar study was conducted and determined the variations in the levels of lipids, fatty acid composition and nutritional profiles of five fish species from the Amazon Basin. The fatty acid composition in the five fish species varied throughout seasonal periods, SFA contents decreased in flood periods, whereas PUFA contents significantly $(p<0.05)$ increased for all the species in the same period. Leporinus friderici showed the highest content of LIN (14.86 $\mathrm{mg} \mathrm{g}^{-1}$ ) and Colossoma macropomum presented the highest content of DHA $\left(26.13 \mathrm{mg} \mathrm{g}^{-1}\right)$ in flood periods. Prochilodus nigricans showed the lowest content of AA in both periods, while Brachyplatystoma flavicans showed the greatest amount of AA $\left(18.77 \mathrm{mg} \mathrm{g}^{-1}\right)$ in drought period and $22.10 \mathrm{mg} \mathrm{g}^{-1}$ in flood period. These findings determined that the variations in the levels of lipids and fatty acid of the fish resulted due to the irregular seasonal variations and the water temperature, which affect the fish diet (Petenuci et al. 2016).

\section{Conclusion}

The release of industrial effluents, agricultural run-off and domestic sewage without treatment into the water bodies is a major source of pollution of water at Harike Wetland. The fluctuation in physico-chemical parameters has also been reported during the present course of the study. WQI, HPI and MI analysis of Harike Wetland represented its poor water quality and hence unfit for human usage as compared to Nangal Wetland. It can be concluded that the water of Harike Wetland is affected by the natural processes during 
Table 18 Saturated fatty acids (\%) in the intestine of Labeo rohita collected from Nangal Wetland (control site) and Harike Wetland (polluted site) during different seasons

\begin{tabular}{|c|c|c|c|c|c|c|}
\hline \multirow{2}{*}{$\begin{array}{l}\text { Sites } \\
\text { Seasons }\end{array}$} & \multicolumn{3}{|c|}{ Nangal Wetland (control site) } & \multicolumn{3}{|c|}{ Harike Wetland (polluted site) } \\
\hline & Rainy & Autumn & Winter & Rainy & Autumn & Winter \\
\hline Lauric acid (C12:0) & $0.36 \pm 0.31^{\mathrm{a}}$ & NIL & NIL & $0.03 \pm 0.01^{\mathrm{a}}$ & NIL & NIL \\
\hline Myristic acid (C14:0) & $0.66 \pm 0.05^{\mathrm{a}}$ & $0.87 \pm 0.38^{\mathrm{a}}$ & $1.33 \pm 0.66^{\mathrm{b}}$ & $0.07 \pm 0.03^{\mathrm{a}}$ & $1.09 \pm 0.29^{\mathrm{b}}$ & $1.27 \pm 0.38^{\mathrm{b}}$ \\
\hline Pentadecanoic acid (C15:0) & $0.18 \pm 0.08^{\mathrm{a}}$ & NIL & NIL & $0.01 \pm 0.00^{\mathrm{a}}$ & $1.00 \pm 0.49^{\mathrm{b}}$ & NIL \\
\hline Palmitic acid (C16:0) & $1.93 \pm 0.03^{\mathrm{b}}$ & $0.82 \pm 0.70^{\mathrm{a}}$ & NIL & NIL & $0.44 \pm 0.28^{\mathrm{b}}$ & $0.02 \pm 0.00^{\mathrm{a}}$ \\
\hline Stearic acid $(\mathrm{C} 18: 0)$ & $0.62 \pm 0.17^{\mathrm{b}}$ & $0.21 \pm 0.10^{\mathrm{a}}$ & NIL & $0.11 \pm 0.00^{\mathrm{b}}$ & NIL & $0.03 \pm 0.00^{\mathrm{a}}$ \\
\hline Eicosanoic acid & $0.18 \pm 0.09^{\mathrm{a}}$ & $0.31 \pm 0.24^{\mathrm{a}}$ & $0.16 \pm 0.11^{\mathrm{a}}$ & $9.07 \pm 3.52^{\mathrm{c}}$ & $0.45 \pm 0.31^{\mathrm{a}}$ & $1.86 \pm 0.49^{\mathrm{b}}$ \\
\hline Octadecanoic acid & $6.28 \pm 0.34^{\mathrm{b}}$ & $17.59 \pm 1.45^{\mathrm{c}}$ & $0.29 \pm 0.18^{\mathrm{a}}$ & $0.21 \pm 0.06^{\mathrm{a}}$ & $5.42 \pm 2.18^{\mathrm{b}}$ & NIL \\
\hline Capric acid (C10:0) & $0.92 \pm 0.01^{\mathrm{a}}$ & $5.51 \pm 0.81^{\mathrm{b}}$ & $4.45 \pm 1.64^{\mathrm{b}}$ & $1.43 \pm 0.67^{\mathrm{a}}$ & $1.01 \pm 0.55^{\mathrm{a}}$ & $3.63 \pm 0.33^{\mathrm{b}}$ \\
\hline Undecylic acid (C11:0) & $3.02 \pm 0.21^{\mathrm{a}}$ & $12.96 \pm 0.28^{\mathrm{c}}$ & $11.08 \pm 0.49^{\mathrm{b}}$ & $3.60 \pm 0.29^{\mathrm{a}}$ & $4.42 \pm 0.41^{\mathrm{a}}$ & $23.62 \pm 2.65^{\mathrm{b}}$ \\
\hline Pentadecylic & $0.14 \pm 0.09^{\mathrm{a}}$ & $0.87 \pm 0.43^{\mathrm{b}}$ & $41.64 \pm 1.10^{\mathrm{c}}$ & $30.68 \pm 4.61^{\mathrm{c}}$ & $2.53 \pm 1.22^{\mathrm{a}}$ & $17.07 \pm 0.48^{\mathrm{b}}$ \\
\hline Margaric acid & $40.60 \pm 3.32^{\mathrm{b}}$ & $14.09 \pm 1.19^{\mathrm{a}}$ & $11.56 \pm 1.69^{\mathrm{a}}$ & $17.55 \pm 0.62^{\mathrm{a}}$ & $56.32 \pm 0.40^{\mathrm{c}}$ & $23.44 \pm 5.67^{\mathrm{b}}$ \\
\hline Total SFAs & $53.01 \pm 3.64^{\mathrm{a}}$ & $50.90 \pm 2.02^{\mathrm{a}}$ & $70.55 \pm 1.28^{\mathrm{b}}$ & $62.78 \pm 1.30^{\mathrm{a}}$ & $72.69 \pm 0.89^{\mathrm{b}}$ & $70.96 \pm 2.15^{\mathrm{b}}$ \\
\hline SFAs/PUFAs & $1.02 \pm 0.18^{\mathrm{b}}$ & $0.93 \pm 0.02^{\mathrm{a}}$ & $4.91 \pm 0.31^{\mathrm{c}}$ & $1.65 \pm 0.06^{\mathrm{a}}$ & $2.74 \pm 0.08^{\mathrm{b}}$ & $3.25 \pm 0.47^{\mathrm{b}}$ \\
\hline
\end{tabular}

Only major SFAs have been included; values are mean + S.E. Values with same superscript in a row with respect to one sampling site during different seasons do not differ significantly $(p>0.05)$

the rainy season, anthropogenic influences from industrial effluents and domestic waste water enriched with heavy metals. Industrial effluent addition into the water bodies is a serious problem and should be inhibited because they can cause environmental persistence, bioaccumulation and biomagnification in the food chain. Furthermore, these pollutants cause reduction in fish organ fatty acid production. It is recommended that stringent legislation and guidelines should be implemented to thwart the direct discharge of pollutants into the natural aquatic ecosystem. The fish processing industries around the world generate large amount of fish waste every year. This waste is having high nutritional value and should be utilized in order to add economic value and to minimize the environmental pollution problems.

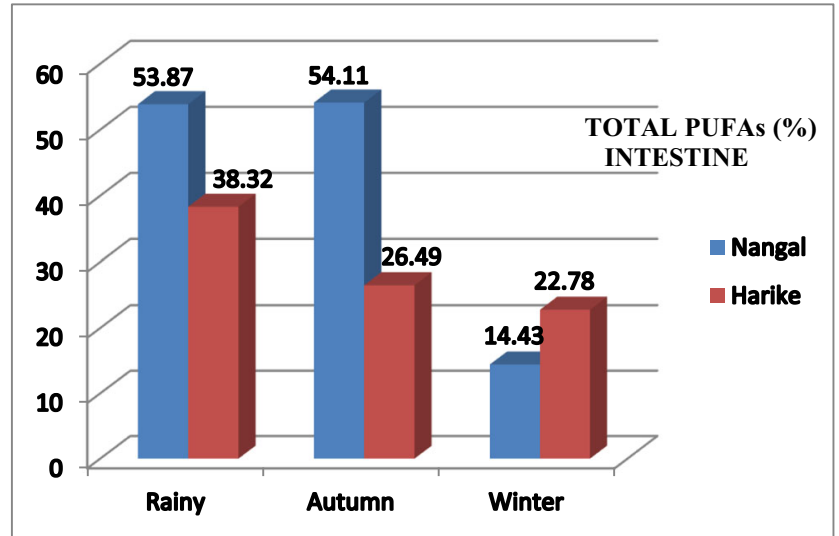

Fig. 5 Total polyunsaturated fatty acid comparison in the intestine of fish, Labeo rohita, collected from different habitats in similar seasons

\section{Statistical analysis}

All values were given as mean \pm standard error of mean. Statistical difference among the mean of various fatty acids of control and test fish sample (liver and intestine) were determined using one-way and multifactor ANOVA. The analysis was done using Microsoft Excel and STATGRAPHICS statistical packages. The statistical calculations, for instance, statistical mean, range and standard deviation of different water quality parameters were made in Microsoft Excel.

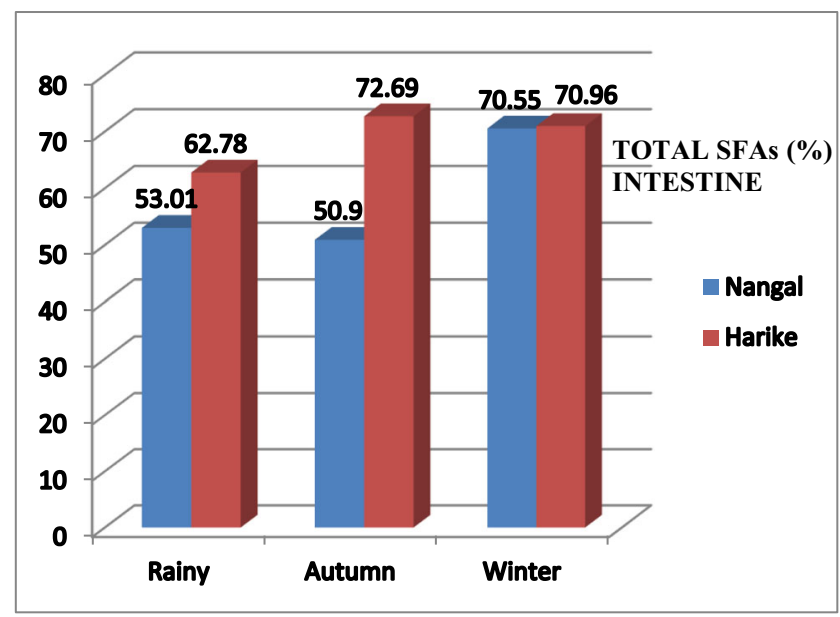

Fig. 6 Total saturated fatty acid comparison in the intestine of fish, Labeo rohita, collected from different habitats in similar seasons 
Acknowledgements The authors wish to acknowledge the University Grants Commission, New Delhi, for their financial support (NFSC fellowship) and also to the Head, Department of Zoology \& Environmental Sciences, Punjabi University, Patiala, Dr. SS Hundal (Professor \& Head, Department of Zoology, Punjab Agricultural University, Ludhiana) for providing necessary facilities to carry out the research work.

Author contribution All authors contributed to the study conception and design. Material preparation, data collection and analysis were performed by Navpreet Kaur. The first and final draft of the manuscript was written by Navpreet Kaur. Editing of manuscript was done by Navpreet Kaur. Review, corrections and checking before final submission were done by Dr. Onkar Singh Brraich.

Funding This work was financially supported by University Grants Commission, New Delhi, providing national fellowship for SC candidate (NFSC fellowship award number: RGNF-2017-18-SC-PUN-31975) assigned to the first author. The authors would like to thank the Editor of ESPR and the reviewers for their collaboration in the improvement of manuscript.

Availability of data and materials All data and material are provided in the results section of this paper.

\section{Declarations}

Ethics approval As this work is on fish and fish is cultivable organism, hence, no ethical approval is required.

Consent to participate Not applicable in this section.

Consent for publication Not applicable.

Competing interests The authors declare no competing interests.

\section{References}

Abedi E, Sahari MA (2014) Long-chain polyunsaturated fatty acid sources and evaluation of their nutritional and functional properties. Food Sci Nutr 2(5):443-463

Adekola FA, Eletta OAA (2007) A study of heavy metal pollution of Asa River, Ilorin, Nigeria: trace metal monitoring and geochemistry. Environ Monit Assess 125:157-163

Akhter S, Brraich OS (2020) Statistical analysis of water quality indices from a Ramsar Site- Ropar Wetland, India. Adv Zool Bot 8(3):132143

Almuktar SAAAN, Abed SN, Scholz M (2018) Wetlands for waste water treatment and subsequent recycling of treated effluent, a review. Environ Sci Pollut Res 25:23595-23623

American Association of Cereal Chemists (1976) Approved methods. The American Association, St Paul Minneapolis, pp 1-795

American Public Health Association (2012) Standard methods for the examination of water and waste water, 21st edn. American Public Health Association, American Water Works Association \& Water Environment Federation, New York

Anawar HM, Chowdhury (2020) Remediation of polluted river water by biological, chemical, ecological and engineering processes. Suistainability $12: 1-18$

Applequist LA, Boynton JE, Stumpf PK, Wettstein DV (1968) Liquid biosynthesis in relation to chloroplast development in barley. J Lipid Res 9:425-436
Association of Analytical Communities (2000) Meat and meat products Official Methods of Analysis, 17th edn. USA: North Frederick Avenue Gaithersburg, Maryland, 20877-2417, Ch. 39: 3-481

Baki AS, Dkhil MA, Quraishy S (2011) Bioaccumulation of some heavy metals in tilapia fish relevant to their concentration in water and sediment of Wadi Hanifa, Saudi Arabia. Afr J Biotechnol 10(13): 2541-2547

Bashir I, Lone FA, Bhat RA, Mir SA, Dar ZA, Dar SA (2020) Concerns and threats of contamination on aquatic ecosystem. In: Hakem KR et al (eds) Bioremediation and biotechnology. Sher-e-Kashmir University of Agricultural Sciences and Technology, Jammu

Bonanno G, Giudice RL (2010) Heavy metal bioaccumulation by the organs of Phragmites australis (common reed) and their potential use as contamination indicators. Ecol Indic 10:639-645

Borga K, Fisk AT, Hoekstra PF, Muir DCG (2004) Biological and chemical factors of importance in the bioaccumulation and trophic transfer of persistent organochlorine contaminants in arctic marine food webs. Environ Toxicol Chem 23:367-2385

Brown RM, Mc Cleiland NJ, Deininger RA, O'Connor MF (1972) A water quality index-crossing the psycho-logical barrier (Ed, Jenkis, S.H.). Proc Int Conf Water Poll Res, Jerusalem 6:787-797

Brraich OS, Jangu S (2015a) Evaluation of water quality pollution indices for heavy metal contamination monitoring in the water of Harike wetland (Ramsar site), India. Int J Sci Res Publ 5(2):1-6

Brraich OS, Jangu S (2015b) Some aspects of reproductive biology on effect of heavy metal pollution on the histopathological structure of gonads in Labeo rohita (Hamilton-Buchanan) from Harike wetland, India. Int J Fish Aquat Studies 7:9-14

Brraich OS, Kaur R (2015) Assessment of physico-chemical parameters and water quality index of Nangal Wetland, Punjab, India. J Env Bio Sci 29(1):33-39

Brraich OS, Saini SK (2015) Water quality index of Ranjit Sagar Wetland situated on the Ravi River of Indus River system. Int J Adv Res 3(12):1498-1509

Caerio S, Costa MH, Ramos TB, Fernandes F, Silveira N, Coimbra A, Painho M (2005) Assessing heavy metal contamination in Sado Estuary sediment: an index analysis approach. Ecol Indic 5:155-169

Chatterji C, Raziuddin M (2002) Determination of water quality index (WQI) of a degraded river in Asanol industrial area, Raniganj, Burdwan, West Bengal. Nat Environ Pollut Technol 1(2):181-189

Dede OT (2016) Application of heavy metal pollution index for surface waters: A case study for Camlidere. J Biol Chem 44(4):499-504

Edet AE, Offiong OE (2002) Evaluation of water quality pollution indices for heavy metal contamination monitoring, a study case from Akpabuyo-Odukpani area, lower river basin (Southeastern Nigeria). Geo J 57:295-304

Giri S, Singh AK (2014) Assessment of surfacewater quality using heavy metal pollution index in Subarnarekha River, India. Water Qual Expo Health 5:173-182

ICMR (1975) In: Manual of standards of quality for drinking water supplies New Delhi: ICMR

ISI (1973) In: Indian standards methods for sampling and test (physical and chemical) for water used in industry. Indian Standard Institute, Mank Bhawan

Jabeen F, Chaudhry AS (2011) Chemical compositions and fatty acid profiles of three freshwater fish species. Food Chem 125(3):991996

Jaidka A (2014) Impact of Buddha Nullah pollution on reproductive health of fish in the river Sutlej. M.Sc. Thesis, Punjab Agricultural University, Ludhiana, India

Javed M, Usmani N, Ahmad I, Ahmad M (2012) Studies on the oxidative stress and gill histopathology in Channa punctatus of the canal receiving heavy metal loaded effluent of Kasimpur Thermal Power Plant. Environ Monit Assess 187:4179 
Johnston TA, Wiegand MD, Szmadyla RL, Casselman JM, Leggett WC (2020) Sex based differences in fatty acid composition of adult Walleye. Ecol Freshw Fish 29(4):654-664

Joyce C (2012) Preface: Wetland services and management. Hydrobiologia 692:1-3

Kamal M, Ghaly AE, Mahmond N, Cote R (2004) Phytoaccumulation of heavy metals by aquatic plants. Environ Int 29:1029-1034

Kanaujja A, Kumar A (2014) Wetlands: significance, threats and conservation. Project report, Department of Zoology, University of Lukhnow, Uttar Pradesh

Kandemir S, Polat N (2007) Seasonal variation of total lipid and total fatty acid in muscle and liver of rainbow trout (Oncorhynchus mykiss) reared in Derbent Dam Lake. Turk J Fish Aquat Sci 7:27-31

Kandyliari A, Mallouchos A, Papandroulakis N, Golla JP, Lam TT, Sakellari A, Karavoltsos S, Vasilliou V, Kapsokefalou M (2020) Nutrient composition and fatty acid and protein profiles of selected fish by-products. Foods 9(190):1-14

Kaur N, Hundal SS, Sehgal GK (2018) Comparative analysis of total lipid content and fatty acid composition of head, liver and intestine from Cyprinus carpio (Linn.) and Ctenopharyngodon idella (Steindachner) of different weight groups. Int J Pure Appl Biosci 6(6):423-427

Khan II, Hazarika AK (2012) Study of some water quality parameters of Kolong riverine system of Nagaon, India. Clarion 1(2):121-129

Li Y, Yu Z, Song X, Mu Q (2006) Trace metal concentrations in suspended particles, sediments and clams from Jiaozhou Bay of China. Environ Monit Assess 121:491-501

Lu Q, He ZL, Graetz DA, Stoffella PJ, Yang X (2011) Uptake and distribution of metals by water lettuce Pistia stratiotes. Environ Sci Pollut Res 18:978-986

Łuczyńska J, Tońska E, Krejszeff F, Żarski D (2016) Comparison of fatty acids in the muscles and liver of pond-cultured and wild perch, Perca fluviatilis (L.), in Poland. Turk J Fish Aquat Sci 16:19-27

Mahboob S, Ghanim KAA, Misned FA, Sahid T, Sultana S, Sultan T, Hussain B, Ahmed Z (2019) Impact of water pollution on trophic transfer of fatty acids in fish, microalgae and zoobenthos in the food web of a freshwater ecosystem. Biomolecules 9:1-17

Matache ML, Marin C, Rozylowicz L, Tudorache A (2013) Plants accumulating heavy metals in the Danube River wetlands. J Environ Health Sci Eng 11:3-9

Mellery J, Geay F, Tocher DR, Kestemont P, Debier C, Rollin X, Larondelle Y (2016) Temperature increase negatively affects the fatty acid bioconversion capacity of rainbow trout (Oncorhynchus mykiss) fed a linseed oil - based diet. PLoS One 11(10):1-24

Mishra VK, Upadhaya AR, Panday SK, Tripathi BD (2008) Concentration of heavy metals and aquatic macrophytes of Govind Ballabh Pant Sagar an anthropogenic lake affected by coal mining effluent. Environ Monit Assess 141:49-58

Mohan SV, Nithila P, Reddy SJ (1996) Estimation of heavy metals in drinking water and development of heavy metal pollution index. J Environ Sci Health A 31:283-289

Oliver L, Dietrich T, Marron I, Villaran MC (2020) Producing omega-3 polyunsaturated fatty acids: a review of sustainable sources and future trends for EPA and DHA market. Resources 1-15

Page V, Feller U (2015) Heavy metals in crop plants: transport and redistribution processes on the whole plant level. Agronomy 5:447463

Pappa JSS, Lenin T, Sundaram AA, Kumar SP (2016) Biochemical changes in estuarine fish Mugil cephalus exposed to industrial effluent. Int J Adv Multi Res 3(1):46-49
Petenuci ME, Rocha INA, Sousa SC, Schneider VVA, Costa LAMA, Visentainer JV (2016) Seasonal variation in lipid content, fatty acid composition and nutritional profile of five freshwater fish from the Amazon Basin. J Am Oil Chem Soc 93(10):1373-1381

Prasad B, Bose JM (2001) Evaluation of the heavy metal pollution index for surface and spring water near a limestone mining area of the lower himalayas. Environ Geol 41(1-2):183-188

Robert A, Mfilnge P, Limbu SM, Mwita C (2014) Fatty acid composition and level of selected polyunsaturated fatty acids in four commercial important freshwater fish species from Lake Victoria, Tanzania. J Lipids 1-7

Rogero MM, Leao MC, Santana TM, Pimentel MV, Carlini GCG, Silveira TFF, Concalves RC, Castro IA (2020) Potential benefits and risks of omega-3 fatty acids supplementation to patients with Covid-19. Free Rad Biol Med 156:190-199

Sahoo MM, Swain JB (2020) Modified heavy metal pollution index (mHPI) for surface water quality in river basins, India. Environ Sci Pollut Res 27:15350-15364

Salah S, Saloua S (2010) The influence of season on lipid content and fatty acid profile of Euthynnus alletteratus fillets and by-products. J Muscle Foods 21:365-378

Souza FA, Dziedzic M, Cubas AS, Maranho LT (2013) Restoration of polluted waters by phytoremediation using Myriophyllum aquaticum (Vell.). J Environ Manag 120:5-9

Sulochana (2016) Evaluation of toxic effect of pollutants on reproductive efficacy of Labeo rohita (Hamilton-Buchanan) from Harike Wetland. Ph.D. Thesis, Punjabi University, Patiala

Tashla T, Zuza M, Kenjves T, Prodanovic R, Solesa D, Burscic V, Petrovic A, Pelic DL, Boskovic J, Puvaca N (2018) Fish as an important bio-indicator of environmental pollution with persistent organic pollutants and heavy metals. J Agron Technol Eng Manag 1(1):52-56

Thakur JS, Prinja S, Singh RA, Arora S, Prasad R, Parwana HK (2014) Genotoxicity and adverse human health outcomes among people living near highly polluted waste water drains in Punjab, India. World J Pharm Res 4:895-908

Trivedi RK, Goel PK (1984) Chemical and biological methods for water pollution studies. Environmental Publications, India

Verma AK, Saksena DN (2010) Assessment of water quality and pollution status of Kalpi (Morar) River, Gwalior, Madhya Pradesh: with special reference to conservation and management plan. Asian J Exp Biol Sci 1(2):419-429

WHO (1992) In: International standards for drinking water. World Health Organisation, Geneva

Zayed A, Gowthaman S, Terry N (1998) Phytoaccumulation of trace elements by wetland plants: I Duckweed. J Environ Qual 27:715721

Zhang X, Xi N, He X, Sun X, Yu X, Cheng Y, Yu R, Wu Y (2020) Fatty acid composition analysis of commercially important fish species from the pearl river Estuary, China. PLoS One 15(1):1-16

Zhu YL, Zayed AM, Qian JH, Souza MD, Terry N (1999) Phytoaccumulation of trace elements by wetland plants: II Water Hyacinth. J Environ Qual 28:339-344

Publisher's note Springer Nature remains neutral with regard to jurisdictional claims in published maps and institutional affiliations. 